\title{
Overview of anthelmintic resistance of gastrointestinal nematodes of small ruminants in Brazil
}

Panorama da resistência anti-helmíntica em nematoides gastrointestinais de pequenos ruminantes no Brasil Jordana Andrioli Salgado' ${ }^{1}$ Clóvis de Paula Santos ${ }^{1 *}$

\author{
${ }^{1}$ Laboratório de Biologia Celular e Tecidual, Centro de Biociências e Biotecnologia - CBB, Universidade Estadual do Norte \\ Fluminense - UENF, Campos dos Goytacazes, RJ, Brasil
}

Received November 12, 2015

Accepted January 18, 2016

\begin{abstract}
Frequent and inappropriate use of all classes of antiparasitic drugs in small ruminants has led to failures in their effectiveness, culminating in a global problem of anthelmintic resistance. Brazil stands out as one of the world's leaders in publications about anthelmintic resistance, and for having the most numerous reports of this resistance in small ruminants in the Americas. These studies have involved mainly the fecal egg count reduction test (FECRT) and its correlation with field management practices. In vivo effectiveness testing is conducted in areas where livestock is of greater economic significance, e.g., in the South (sheep) and Northeast (goats), or is important for research and economic centers, such as the Southeast (sheep). The most widely studied species is sheep, for which the widest range of drugs is also evaluated. Despite significant advances achieved in molecular research, laboratory analyses should include knowledge about the reality in the field so that they can become feasible for the producer. Moreover, molecular studies can be underpinned by the analysis of field studies, such as the maintenance of antiparasitic effectiveness over time and the mechanisms involved in this process.
\end{abstract}

Keywords: Small ruminants, anthelmintic resistance, sheep, goat, gastrointestinal nematodes.

\section{Resumo}

O uso frequente e inapropriado de todas as classes de antiparasitários em pequenos ruminantes levou a falhas de eficácia, culminando na problemática global de resistência anti-helmíntica. O Brasil destaca-se como sendo um dos pioneiros nas publicaçóes com resistência anti-helmíntica no mundo e por ter o maior número de relatos em pequenos ruminantes na América. Essas pesquisas envolvem principalmente o teste da redução da contagem de ovos nas fezes (TRCOF) e sua correlação com as práticas de manejo utilizadas no campo. Os estudos de testes de eficácia in vivo localizam-se em áreas onde há maior importância dos rebanhos como nas Regiōes Sul (ovinos) e Nordeste (caprinos), ou com importância em polos de pesquisa e econômicos, como a região Sudeste (ovinos). Ovina é a espécie mais estudada e com maior gama de drogas avaliadas. Mesmo com grande avanço em pesquisas moleculares, as análises laboratoriais devem envolver o conhecimento da realidade do campo para que possam se tornar viáveis ao produtor. Além disso, a análise dos estudos de campo pode nortear estudos moleculares como, por exemplo, a manutenção da eficácia das drogas ao longo dos anos e os mecanismos envolvidos em tal processo.

Palavras-chave: Pequenos ruminantes, resistência anti-helmíntica, ovelha, cabra, nematoides gastrointestinais.

\section{Introduction}

The worldwide production of small ruminants is strongly impacted by gastrointestinal parasites that cause high mortality rates (HOSTE \& TORRES-ACOSTA, 2011; STEAR et al., 2011; KNOX et al., 2012; FALZON et al., 2014), as well as losses resulting from subclinical infections that are reflected in low productivity (CHARLIER et al., 2014). In tropical countries, Haemonchus contortus

*Corresponding author: Clóvis de Paula Santos. Laboratório de Biologia Celular e Tecidual, Centro de Biociências e Biotecnologia - CBB, Universidade Estadual do Norte Fluminense - UENF, Av. Alberto Lamego, 2000, CEP 28013-602, Campos dos Goytacazes, RJ, Brasil. e-mail: cps@uenf.br is the most prevalent nematode in herds, causing severe losses due to the high pathogenic pressure it exerts through hematophagy (KASSAI, 1999). Other parasites also contribute to losses through diarrhea, spoliation of intestinal mucosa and anemia, mainly because of mixed infections, which cause a variety of clinical signs and low productivity (MOLENTO et al., 2009). In Brazil, the productive potential for ruminants that are suitable for animal husbandry is hampered by endoparasitic infections. In the cattle sector, where the country is a world leader in commercial herds, annual losses caused by gastrointestinal parasites are estimated to reach up to 
\$ 7.11 billion (GRISI et al., 2014). Sheep and goats, for which there is a developing production chain in the country, are even more susceptible, and their high mortality rate is a significant deterrent to agribusiness.

Over the years, parasitic diseases in livestock have been controlled based on the use of broad-spectrum and widely accessible antiparasitics. The main classes of anthelmintics available in recent years are: benzimidazoles, imidazothiazoles, macrocyclic lactones, salicylanilides and nitrophenols (COLES et al., 2006). According to Molento (2009), the use of antiparasitic drugs in farm animals over the years offers benefits; however, the continuous and inappropriate use of these drugs has resulted in the loss of effectiveness of many active ingredients. Macrocyclic lactones were launched on the market in the 1980s (CHABALA et al., 1980), but just a few years later, there were reports of the loss their efficiency in Brazil (ECHEVARRIA \& TRINDADE, 1989). Recently, two new classes of anthelmintics were launched, an amino-acetonitrile derivative, monepantel (KAMINSKY et al., 2008), and derquantel, which was marketed in association with abamectin (LITTLE et al., 2010). However, there have been reports of resistance to monepantel (SCOTT et al., 2013; MEDEROS et al., 2014a; VAN DEN BROM et al., 2015) and to derquantel (KAMINSKY et al., 2011), indicating the high vulnerability of these drugs. Additional to the loss of effectiveness there are the effects of toxic residues on nontarget organisms in the environment (LUMARET et al., 2012) and of residues in meat (COOPER et al., 2011), milk and other animal products associated to anthelmintics (IMPERIALE et al., 2004; ANASTASIO et al., 2005; WHELAN et al., 2010).

According to the guidelines of the World Association for the Advancement of Veterinary Parasitology- WAAVP, occurs anthelmintic resistance (AHR) when the effectiveness of a drug against the target parasite load is lower than 95\% (COLES et al., 1992, 2006). AHR occurs when there is high incidence of individuals in a parasite population that are able to tolerate doses of a presumably lethal compound, and this characteristic is hereditary (PRICHARD et al., 1980). This decrease in susceptibility is caused by an increase in the genetic selection frequency, which results from repeated use of an anthelmintic (FLEMING et al., 2006). The greater the selective pressure of the drug, the greater the process of selection by resistant organisms. According to Blouin et al. (1995), gastrointestinal nematodes of small ruminants have genetic traits that promote the rapid development of AHR, such as rapid rates of selection and of gene flow and a high level of genetic diversity. As a result, these parasites have the genetic potential to quickly respond to the effect of anthelmintics and the means to ensure the dissemination of their resistant genes (FLEMING et al., 2006).

Increased AHR in herds has led to the need to identify management practices that can reduce the impact of the problem (FALZON et al., 2014), which requires a prior diagnosis of the situation. AHR in small ruminants has been reported in various regions of world: Argentina (EDDI et al., 1996); Uruguai (NARI et al., 1996; BONINO \& MEDEROS, 2003), Paraguai (MACIEL et al., 1996); South Africa (VAN WYK et al., 1997); Mexico (TORRES-ACOSTA et al., 2003); Australia (SUTER et al., 2004; PLAYFORD et al., 2014); New Zealand (WAGHORN et al., 2006); Canada (FALZON et al., 2013); Denmark (PENA-
ESPINOZA et al., 2014); Uganda (NABUKENYA et al., 2014); Italy (ZANZANI et al., 2014); Ireland (KEANE et al., 2014); France, Greece and Italy (GEURDEN et al., 2014). The countries with the largest number of cross-sectional studies over time are New Zealand, the United Kingdom and Brazil (FALZON et al., 2014). Torres-Acosta et al. (2012) also highlight Brazil as the country with the largest number of publications in the area that offer up-to-date reports about the situation of AHR in the Americas. Thus, the purpose of this review is to provide an overview of the reports of AHR in small ruminants in Brazil, discussing the history and forms of diagnosis employed; and to analyze the distribution of surveys by region, as well as the evolution of the use, effectiveness and maintenance of these drugs over the years.

\section{History of AHR in Small Ruminants in Brazil and Around the World}

The world's first report of AHR involved the drug phenothiazine in sheep in the U.S. (LELAND et al., 1957). Among the classes of anthelmintics currently in use, benzimidazoles were the first drugs to lose their effectiveness in nematodes of small ruminants, and AHR in sheep to thiabendazole was first reported by Drudge et al. (1964). Soon thereafter, in Brazil, Santos \& Gonçalves (1967) reported the first case of anthelmintic resistance in sheep to thiabendazole in the state of Rio Grande do Sul. In goats, first reported resistance to benzimidazole in the world occurred in the 1980s (LUTU, 1984; KETTLE et al., 1983; McKENNA, 1984). In Brazil, based on the necropsy of goats treated with albendazole, parbendazole and levamisole, Charles et al. (1989) reported resistance to all these active ingredients, and questioned whether the dosage was correct for the species. In the same year, Vieira et al. (1989) detected resistance to several classes of benzimidazole in goats in the state of Ceará.

The nematode strains resistant to benzimidazole were highly susceptible to imidazothiazoles, but in Australia, Le Jambre et al. (1976) reported the potential resistance of nematode strains selected in vitro to these drugs, and their report was soon followed by other reports about resistance around the world, including field strains (KELLY \& HALL, 1979). In Brazil, a previous report by Santiago et al. (1977) identified a strain of Trichostrongylus colubriformis resistant to levamisole. Later, Green et al. (1981) published the first report of multiple resistance, including to benzimidazoles and imidazothiazoles, caused by the high selection pressure resulting from frequent treatments of sheep flocks in Queensland, Australia. In Brazil, articles about goats in the state of Pernambuco (CHARLES et al., 1989) and about sheep in the state of São Paulo (AMARANTE et al., 1992) reported resistance to levamisole as multiple with the other formulations of benzimidazoles.

With the advent of AHR to the two main classes of anthelmintics in the animal market, the emergence of a new class offered new prospects for Brazilian livestock. In the 1980s, macrocyclic lactones with endectocide activity were launched on the French market (CHABALA et al., 1980), and were soon thereafter launched in Brazil in various formulations and concentrations. The first report of loss of ivermectin effectiveness in sheep was published in South 
Africa (CARMICHAEL et al., 1987), and was soon followed by reports in Brazil (ECHEVARRIA \& TRINDADE, 1989). In Brazil, the first report of ivermectin resistance in goats dates from the 1990s in the state of Rio Grande do Sul (MATTOS et al., 1997 cited by MATTOS et al., 2004). Melo et al. (2003) also reported resistance to ivermectin in sheep and goats in the state of Ceará, and this report was followed by others throughout the country.

Over time and with the use of new drugs, there have been numerous reports of multiple resistance worldwide, especially in countries with a tradition of breeding small ruminants. In Brazil, in addition to the aforementioned classes of drugs, Thomaz-Soccol et al. (1996) reported multiple resistances in sheep in the state of Paraná to the drugs closantel and disophenol, which are still considered specific and effective in the treatment of $H$. contortus. Also in the state of Paraná, Cunha et al. (1998) found resistance to moxidectin, a milbemectin of the class of macrocyclic lactones, which was effective against ivermectin resistant strains (CRAIG et al., 1992). Subsequent reports of multiple resistance to the macrocyclic lactones ivermectin and moxidectin (CONDER et al., 1993; SHOOP et al., 1993) raised the possibility of cross-resistance between them (MOLENTO et al., 1999). In addition to other drugs, Cezar et al. 2010 and Cruz et al. 2010 reported resistance to nitroxynil, a narrow spectrum anthelmintic that had until then been effective against Haemonchus spp.

In the absence of the release of new drugs, and given the increasing status of AHR in small ruminants, combinations of drugs with different mechanisms of action began to be used in an effort to delay the development of resistance (SMITH, 1990; COLES \& ROUSH, 1992). However, it was found that these combinations could fail, particularly when there was already resistance to one or more drugs, although the use of combinations was found to be valid when inserted in integrated programs of drug resistance management and underpinned by parasitological examinations (LEATHWICK \& BESIER, 2014). In Brazil, resistance to various combinations of antiparasitics were reported in sheep in the state of Paraná by Thomaz-Soccol et al. (1996) and ThomazSoccol et al. (2004), in Rio Grande do Sul by Echevarria et al. (1996) and Cezar et al. (2010), and in Mato Grosso do Sul by Sczesny-Moraes et al. (2010) (see Table 1).

Recently, two new classes of anthelmintics were launched, a derivative of aminoacetonitrile with broad-spectrum activity, monepantel, Zolvix ${ }^{\oplus}$ (KAMINSKY et al., 2008) and derquantel

Table 1. Papers published regarding Anthelmintic Resistance, evaluated by the Fecal Egg Count Reduction Test (FECRT), in small ruminants in Brazil.

\begin{tabular}{|c|c|c|c|c|c|}
\hline State & Anthelmintics evaluated & Drugs with AHR & $\begin{array}{l}\text { Animal } \\
\text { species }\end{array}$ & $\begin{array}{c}\text { No. of farms/ } \\
\text { animals }\end{array}$ & Source \\
\hline RS & Th, Di, P & Th & Sheep & $2 / 308$ & Santos \& Gonçalves (1967) \\
\hline RS & I & I & Sheep & $1 / 89$ & Echevarria \& Trindade (1989) \\
\hline CE & O, F, A, Th. & $\mathrm{O}, \mathrm{F}, \mathrm{A}, \mathrm{Th}$ & Goats & $1 / 25$ & Vieira et al. (1989) \\
\hline SP & $\mathrm{O}, \mathrm{I}, \mathrm{L}$ & $\mathrm{O}, \mathrm{I}, \mathrm{L}$ & Sheep & $9 / 540$ & Amarante et al. (1992) \\
\hline $\mathrm{CE}$ & Tr, N, I & $\mathrm{Ne}, \mathrm{I}$ & Sheep & $1 / 20$ & Vieira et al. (1992) \\
\hline PR & A, C, L, F, I, Te, Di + Te. & $\mathrm{A}, \mathrm{C}, \mathrm{L}, \mathrm{F}, \mathrm{I}, \mathrm{Te}, \mathrm{D}+\mathrm{Te}$ & Sheep & $6 / 480$ & Thomaz-Soccol et al. (1996) \\
\hline RS & $\mathrm{A}, \mathrm{L}, \mathrm{I}, \mathrm{C}, \mathrm{A}+\mathrm{L}$ & $A, L, I, C, A+L$ & Sheep & $182 / \mathrm{NI}$ & Echevarria et al. (1996) \\
\hline RS & $\mathrm{I}, \mathrm{L}, \mathrm{A}, \mathrm{F}, \mathrm{O}, \mathrm{Me}$ & $\mathrm{L}, \mathrm{A}, \mathrm{F}, \mathrm{O}, \mathrm{Me}$ & Sheep & $29 / 870$ & Farias et al. (1997) \\
\hline PR & $\mathrm{I}, \mathrm{A}, \mathrm{M}$ & $\mathrm{I}, \mathrm{A}, \mathrm{M}$ & Sheep & $10 / 850$ & Cunha et al. (1998) \\
\hline $\mathrm{CE}$ & $\mathrm{C}, \mathrm{O}$ & $\mathrm{C}, \mathrm{O}$ & Sheep & $1 / 38$ & Melo et al. (1998) \\
\hline $\mathrm{CE}$ & $\mathrm{I}, \mathrm{C}$ & $\mathrm{I}, \mathrm{C}$ & Goats & $1 / 29$ & Melo et al. (1998) \\
\hline CE & $\mathrm{O}, \mathrm{L}$ & $\mathrm{O}, \mathrm{L}$ & Goats & $34 / 1020$ & Vieira \& Cavalcante (1999) \\
\hline $\mathrm{RS}$ & $\mathrm{C}, \mathrm{L}(8$ and $11 \mathrm{mg} / \mathrm{kg})$ & $\mathrm{C}, \mathrm{L}(8$ and $11 \mathrm{mg} / \mathrm{kg})$ & Goats & $1 / 40$ & Mattos et al. (2000) \\
\hline SC & $\mathrm{I}, \mathrm{L}, \mathrm{C}, \mathrm{A}$ & $\mathrm{I}, \mathrm{L}, \mathrm{C}, \mathrm{A}$ & Sheep & $65 / 7529$ & Ramos, et al. (2002) \\
\hline $\mathrm{CE}$ & $\mathrm{O}, \mathrm{L}, \mathrm{I}$ & $\mathrm{O}, \mathrm{L}, \mathrm{I}$ & Sheep & $16 / 768$ & Melo et al. (2003) \\
\hline CE & $\mathrm{O}, \mathrm{L}, \mathrm{I}$ & $\mathrm{O}, \mathrm{L}, \mathrm{I}$ & Goats & $7 / 336$ & Melo et al. (2003) \\
\hline $\mathrm{CE}$ & $\mathrm{O}$ & $\mathrm{O}$ & Sheep & $6 / 144$ & Melo et al. (2004) \\
\hline RS & I & I & Goats & $2 / 12$ & Mattos et al. (2004) \\
\hline PR & $\mathrm{O}, \mathrm{I}, \mathrm{C}, \mathrm{C}+\mathrm{O}, \mathrm{L}, \mathrm{M}$ & $\mathrm{O}, \mathrm{I}, \mathrm{C}, \mathrm{C}+\mathrm{O}, \mathrm{L}, \mathrm{M}$ & Sheep & $42 / \mathrm{NI}$ & Thomaz-Soccol et al. (2004) \\
\hline $\mathrm{AL}$ & $\mathrm{I}, \mathrm{A}, \mathrm{M}$ & $\mathrm{I}, \mathrm{A}$ & Goats & $1 / 40$ & Ahid et al. (2007) \\
\hline SP & $A+L+I, M$ & M & Sheep & $1 / 24$ & Buzzulini et al. (2007) \\
\hline SC & $\mathrm{I}, \mathrm{A}, \mathrm{M}, \mathrm{C}, \mathrm{L}$ & $\mathrm{I}, \mathrm{A}, \mathrm{M}, \mathrm{C}, \mathrm{L}$ & Sheep & $9 / 450$ & Rosalinski-Moraes et al. (2007) \\
\hline PB & A, I, L, M & $A, I$ & Goats & $\mathrm{n} / 120$ & Rodrigues et al. (2007) \\
\hline PR & $\mathrm{C}+\mathrm{A}, \mathrm{I}(3.5 \%)$ & $C+A, I(3.5 \%)$ & Sheep & $4 / 120$ & Cunha et al. (2008) \\
\hline $\mathrm{RN}$ & $A, I$ & $\mathrm{~A}, \mathrm{I}$ & Sheep & $1 / 54$ & Pereira et al. (2008) \\
\hline $\mathrm{RN}$ & A, I & A, I & Goats & $1 / 54$ & Pereira et al. (2008) \\
\hline
\end{tabular}

A: albendazole; O: oxfendazole; F: febendazole; P: pyrantel tartrate; Th: thiabendazole; Te: tetramisole; L: levamisole; D: doramectin; I: ivermectin; M: moxidectin; C: closantel; Tr: trichloform; N: nitroxynil; Di: disophenol; Ne: netobimin (pre-benzimidazole); Me: mebendazole; Mo: monepantel; (+):associations of drugs. (NI): not informed. (-): no drug presented AHR. Remark: Goats require different doses of anthelmintics to sheep and in general this is not taken into account when considering the status of susceptibility or resistance. 
Table 1. Continued...

\begin{tabular}{|c|c|c|c|c|c|}
\hline State & Anthelmintics evaluated & Drugs with AHR & $\begin{array}{c}\text { Animal } \\
\text { species }\end{array}$ & $\begin{array}{c}\text { No. of farms/ } \\
\text { animals }\end{array}$ & Source \\
\hline MG & $\begin{array}{c}\mathrm{A}+\mathrm{I}+\mathrm{C}, \mathrm{A}+\mathrm{I}+\mathrm{C}+\mathrm{L}+\text { Sele- } \\
\text { nium }\end{array}$ & - & Goats & $1 / 27$ & Silva et al. (2008) \\
\hline RS & Mo, I & I & Sheep & $1 / 30$ & Bustamante et al. (2009) \\
\hline PR & $\mathrm{Tr}, \mathrm{C}$ & $\mathrm{C}$ & Sheep & $1 / 27$ & Falbo et al. (2009) \\
\hline $\mathrm{CE}$ & $\mathrm{O}$ & $\mathrm{O}$ & Sheep & $18 / 432$ & Melo et al. (2009) \\
\hline CE & $\mathrm{O}$ & $\mathrm{O}$ & Goats & $7 / 168$ & Melo et al. (2009) \\
\hline RS & A, I, N, Di, Tr, C, I+ L + A & A, I, N, Di, Tr, C, I+ L + A & Sheep & $1 / 5000$ & Cezar et al (2010) \\
\hline RJ & $\mathrm{N}, \mathrm{D}, \mathrm{L}, \mathrm{I}, \mathrm{A}, \mathrm{C}, \mathrm{M}, \mathrm{F}$ & $\mathrm{N}, \mathrm{D}, \mathrm{L}, \mathrm{I}, \mathrm{A}, \mathrm{C}, \mathrm{M}, \mathrm{F}$ & Sheep & $10 / 800$ & Cruz et al. (2010) \\
\hline $\mathrm{PB}$ & $\mathrm{I}, \mathrm{L}, \mathrm{A}$ & $\mathrm{I}, \mathrm{L}, \mathrm{A}$ & Goats & $8 / 264$ & Lima et al. (2010a) \\
\hline PE & M, I, A & A & Sheep & $3 / \mathrm{NI}$ & Lima et al. (2010b) \\
\hline PE & M, I, A & $\mathrm{M}, \mathrm{I}, \mathrm{A}$ & Goats & 6/NI & Lima et al. (2010b) \\
\hline MS & $\mathrm{A}, \mathrm{I}, \mathrm{L}, \mathrm{Tr}, \mathrm{M}, \mathrm{C}, \mathrm{A}+\mathrm{I}+\mathrm{L}$ & $\mathrm{A}, \mathrm{I}, \mathrm{L}, \mathrm{Tr}, \mathrm{M}, \mathrm{C}, \mathrm{A}+\mathrm{I}+\mathrm{L}$ & Sheep & $16 / 120$ & Sczesny-Moraes et al. (2010) \\
\hline $\mathrm{RN}$ & $\mathrm{I}, \mathrm{A}$ & I, A & Goats & $30 / 1350$ & Coelho et al. (2010) \\
\hline SP & $\mathrm{I}, \mathrm{A}, \mathrm{M}, \mathrm{C}, \mathrm{L}, \mathrm{Tr}$ & $\mathrm{I}, \mathrm{A}, \mathrm{M}, \mathrm{C}, \mathrm{L}, \mathrm{Tr}$ & Sheep & $1 / 42$ & Almeida et al. (2010) \\
\hline SP & $\mathrm{I}, \mathrm{A}, \mathrm{M}, \mathrm{C}, \mathrm{L}$ & $\mathrm{I}, \mathrm{A}, \mathrm{M}, \mathrm{C}, \mathrm{L}$ & Sheep & 30 & Veríssimo et al. (2012) \\
\hline SP & $\mathrm{Tr}, \mathrm{I}, \mathrm{A}, \mathrm{M}, \mathrm{C}, \mathrm{L}$ & $\mathrm{I}, \mathrm{A}, \mathrm{M}, \mathrm{C}, \mathrm{L}$ & Sheep & $1 / 42$ & Chagas et al. (2013) \\
\hline PR & $\begin{array}{c}\mathrm{L}(9 \mathrm{mg} / \mathrm{kg}, 6.75 \mathrm{mg} / \mathrm{kg} \text { and } \\
4.5 \mathrm{mg} / \mathrm{kg})\end{array}$ & $\mathrm{L}(4.5 \mathrm{mg} / \mathrm{kg})$ & Sheep & $1 / 28$ & Sprenger et al. (2013) \\
\hline PR & $\begin{array}{c}\mathrm{L}(9 \mathrm{mg} / \mathrm{kg}, 6.75 \mathrm{mg} / \mathrm{kg} \text { and } \\
4.5 \mathrm{mg} / \mathrm{kg})\end{array}$ & $\begin{array}{c}\mathrm{L}(9 \mathrm{mg} / \mathrm{kg}, 6.75 \mathrm{mg} / \mathrm{kg} \text { and } \\
4.5 \mathrm{mg} / \mathrm{kg})\end{array}$ & Goats & $1 / 28$ & Sprenger et al. (2013) \\
\hline SC & $\mathrm{C}, \mathrm{Tr}, \mathrm{A}, \mathrm{Di}, \mathrm{L}, \mathrm{M}, \mathrm{I}, \mathrm{I}+\mathrm{C}$ & $\mathrm{C}, \mathrm{T}, \mathrm{A}, \mathrm{L}, \mathrm{M}, \mathrm{I}, \mathrm{I}+\mathrm{C}$ & Sheep & $1 / 82$ & Oliveira et al. (2014) \\
\hline PR & $\mathrm{N}, \mathrm{I}$ & $\mathrm{N}, \mathrm{I}$ & Sheep & $1 / 29$ & Vila Nova et al. (2014) \\
\hline PR & Mo & Mo & Sheep & 130 & Cintra et al. (2016) \\
\hline
\end{tabular}

A: albendazole; O: oxfendazole; F: febendazole; P: pyrantel tartrate; Th: thiabendazole; Te: tetramisole; L: levamisole; D: doramectin; I: ivermectin; M: moxidectin; C: closantel; Tr: trichloform; N: nitroxynil; Di: disophenol; Ne: netobimin (pre-benzimidazole); Me: mebendazole; Mo: monepantel; (+):associations of drugs. (NI): not informed. (-): no drug presented AHR. Remark: Goats require different doses of anthelmintics to sheep and in general this is not taken into account when considering the status of susceptibility or resistance.

(Startect $\left.{ }^{\odot}\right)$, a medium-spectrum semisynthetic spiroindolone, which was marketed in association with abamectin (LITTLE et al., 2010, 2011). Sager et al. (2012) found 100\% and 95\% effectiveness, respectively, for these two products against Haemonchus contortus strains resistant to other drugs. Bustamante et al. (2009) found that monepantel was $100 \%$ effective in sheep in Brazil, Argentina and Uruguay. However, resistance to monepantel (SCOTT et al., 2013; MEDEROS et al., 2014a; VAN DEN BROM et al., 2015) and to derquantel (KAMINSKY et al., 2011) has been reported around the world, demonstrating the high vulnerability of these drugs. It is likely that reports of resistance to these anthelmintics will soon be published in Brazil. Therefore, the consensus of the scientific community is that, in view of the high vulnerability of the effectiveness of anthelmintics, allopathic treatment should not be the only form of antiparasitic treatment, and that the focus should be on correlating animal handling, nutrition and alternative forms of parasite control.

\section{Diagnostic Methods Employed in Brazil to Detect AHR in Small Ruminants}

The growing concern about AHR has led to the need for adequate and standardized methods for its detection (COLES et al., 1992). It is important to obtain an accurate and early diagnosis of resistance to assist in parasite control, so as to preserve the useful life of anthelmintics and limit the development of parasitic resistance (TAYLOR et al., 2002; DEMELER et al., 2010). According to Coles et al. (2006), if there is a consensus about delaying the onset of AHR, tests are needed that are able to detect the status of the problem on farms, so that anthelmintic management actions can be planned. Over the years, the WAAVP has discussed methods for the evaluation of AHR in ruminants and other animals, which often involve in vivo, in vitro, and more recently, molecular methodologies (POWERS et al., 1982; COLES et al., 1992; WOOD et al., 1995; COLES et al., 2006).

In Brazil, a concern about standardizing tests has been demonstrated through the promotion of courses and technical manuals for the diagnosis of AHR in ruminants. The Brazilian Agricultural Research Corporation - EMBRAPA-Sudeste has offered courses on "In vitro methodologies for the evaluation of substances with antiparasitic potential on gastrointestinal nematodes of ruminants" given by professionals from around the country. EMBRAPA published a document entitled "Determination of Anthelmintic Effectiveness in Sheep Flocks: Methodology for Specimen Collection and Information on Animal Health Management" (NICIURA et al., 2009). In addition, it also launched the "Practical Manual: Diagnostic methodologies of resistance and detection of active substances in ruminant parasites" (CHAGAS et al., 2011). The document covers in vivo testing and field sampling of material, including questionnaires for producers, while the manual emphasizes in vitro and molecular laboratory 
tests. Fortes \& Molento (2013) wrote a review of the advances and limitations in the diagnosis of AHR in small ruminants, and pointed out the need for accurate diagnostics for the performance of antiparasitic management.

The new molecular biology tools, which are highly accurate, can be used for the diagnosis of susceptible and resistant parasites (CHAGAS et al., 2011). Molecular tests based on the analysis of polymorphisms in the target gene associated with resistance, using PCR, are highly sensitive (SILVESTRE \& HUMBERT, 2000), do not require fecal cultures, and can supplement traditional diagnostic methods (NUNES et al., 2013). However, due to the extremely polygenic nature of populations, researchers have yet to discover the mechanism of drug resistance and pinpoint one or more candidates for specific markers (FORTES \& MOLENTO, 2013). Knowledge about the molecular mechanisms of AHR is still limited mainly to benzimidazoles (COLES et al., 2006; TAYLOR et al., 2002), involving a mutation of tyrosine to phenylalanine in the beta-tubulin gene (SILVESTRE \& HUMBERT, 2000). This polymorphism has also more recently been associated with resistance to avermectins (MOTTIER \& PRICHARD, 2008). In Brazil, Nunes et al. (2013) evaluated goat, sheep and buffalo herds with respect to the presence of polymorphism which confers resistance to benzimidazole, and stated that molecular diagnosis is the guide of choice for anthelmintic drugs before they are used on the herd. Studies of molecular tests on AHR in Brazil have also been evaluated, involving testing of beta-tubulin mutations (NICIURA et al., 2012) or genetic evaluations of nematodes, corroborating researches into AHR (SILVA et al., 2015; SANTOS et al., 2014; AMARANTE et al., 2014; BRASIL et al., 2012).

In vitro tests, also called phenotypic tests, were developed to determine the efficacy of substances on parasites, according to the mode of action of the drug or substance, and also to identify new active ingredients (CHAGAS et al., 2011). The methodologies involve the assessment of the inhibition of hatchability, motility, development and larval feeding for nematodes of cattle, sheep, goats and horses (TAYLOR et al., 2002; COLES et al., 2006; ÁLVAREZ-SÁNCHEZ et al., 2005). In vitro evaluations are also used to confirm or collaborate with field tests (VÁDARY et al., 2007). In Brazil, in vitro assays focus primarily on the evaluation of plants with anthelmintic potential. The search for natural substances with antiparasitic effects is justified by the widespread ineffectiveness of anthelmintic drugs in small ruminants in recent years, and numerous plants and their extracts have been tested in the country. In a review of the subject in Brazil, Nery et al. (2009) compiled in vitro data of studies on 64 plant species, 27 of which showed higher than $90 \%$ efficacy, and 15 showed more than 95\% efficacy in inhibiting the development of trichostrongylids, indicating the potential for research in this area, given the country's vast array of flora.

In vivo trials assess the reduction of the parasite load in the host, by means of necropsy or by anthelmintic post-treatment parasitological examinations. The controlled reduced parasitic load test, which is performed after the autopsy of the animal, evaluates the real situation of parasite elimination in the host (WOOD et al., 1995). However, it requires killing the animals and its cost is high, so it is not widely used (FORTES \& MOLENTO,
2013). The standard method is the fecal egg count reduction test (FECRT) and is the method most widely employed to evaluate the effectiveness of drugs in animals in the field (COLES et al., 2006; TAYLOR et al., 2002). This method enables several drugs to be evaluated simultaneously and consists in examining groups of animals treated with anthelmintics to determine eggs per gram of feces (EPG) before and after treatment; a drug that reduces $95 \%$ of the parasite load is considered effective (COLES et al., 2006). The FECRT can be performed by means of an overall count of strongyle eggs (Strongylida) or individual counts of parasitic genera through fecal culture (MCKENNA, 1997). Albeit very common, there are several limitations inherent to the interactions between host, parasite and the environment (LEVECKE et al., 2012), and there are variations in the calculation formula (MILLER et al., 2006), in the need for control groups (MCKENNA, 2013, 2014), and in use of arithmetic (COLES et al., 1992, 2006) or geometric means (SMOTHERS et al., 1999; DOBSON et al., 2009) in the calculation. According to Falzon et al. (2014), the various methods to calculate FECRT are influenced by the level of AHR and if a bias correction is used in the formula, so it is important to analyze each case. In Brazil, the FECRT is the test most widely used for the assessment of AHR in small ruminants, and is discussed in numerous publications in various regions of the country (Table 1).

\section{Distribution of AHR Surveys in Brazil}

Surveys on anthelmintic resistance in small ruminants around the world are distributed in countries where the species are of the greatest economic importance, such as Australia, New Zealand, South Africa, Uruguay and Brazil. Even with the production chain of small ruminants under development, Brazil stands out for the number of surveys on the subject (TORRES-ACOSTA et al., 2012), and it is a major producer of multidisciplinary scientific material on sheep and goats (RESENDE et al., 2010). In Brazil, surveys on anthelmintic resistance in small ruminants, evaluated by FECRT, are distributed in the regions that have the largest sheep and goat flocks, i.e., the South and Northeast, or where there are large economic centers of activity, as in the case of the Southeast region (Figure 1). The next sections describe the surveys that have been conducted in these areas, and the papers published in the country, which are listed in Table 1.

\section{Northeast region}

The production systems in the Northeast are characterized by family subsistence farming, and include the production of meat and milk, mostly for national school lunch programs and to combat child malnutrition among the poor (CARDOSO et al., 2010). Despite the semi-arid climate of the region, the brief rainy season is characterized by parasitic infections due to extensive systems and precarious sanitary management (PINHEIRO et al., 2000). In this region, due to the size of the herds, there are important research centers in small ruminants that significantly contribute to the national survey. Therefore, there are numerous publications about AHR in small ruminants, especially in goats, and the 


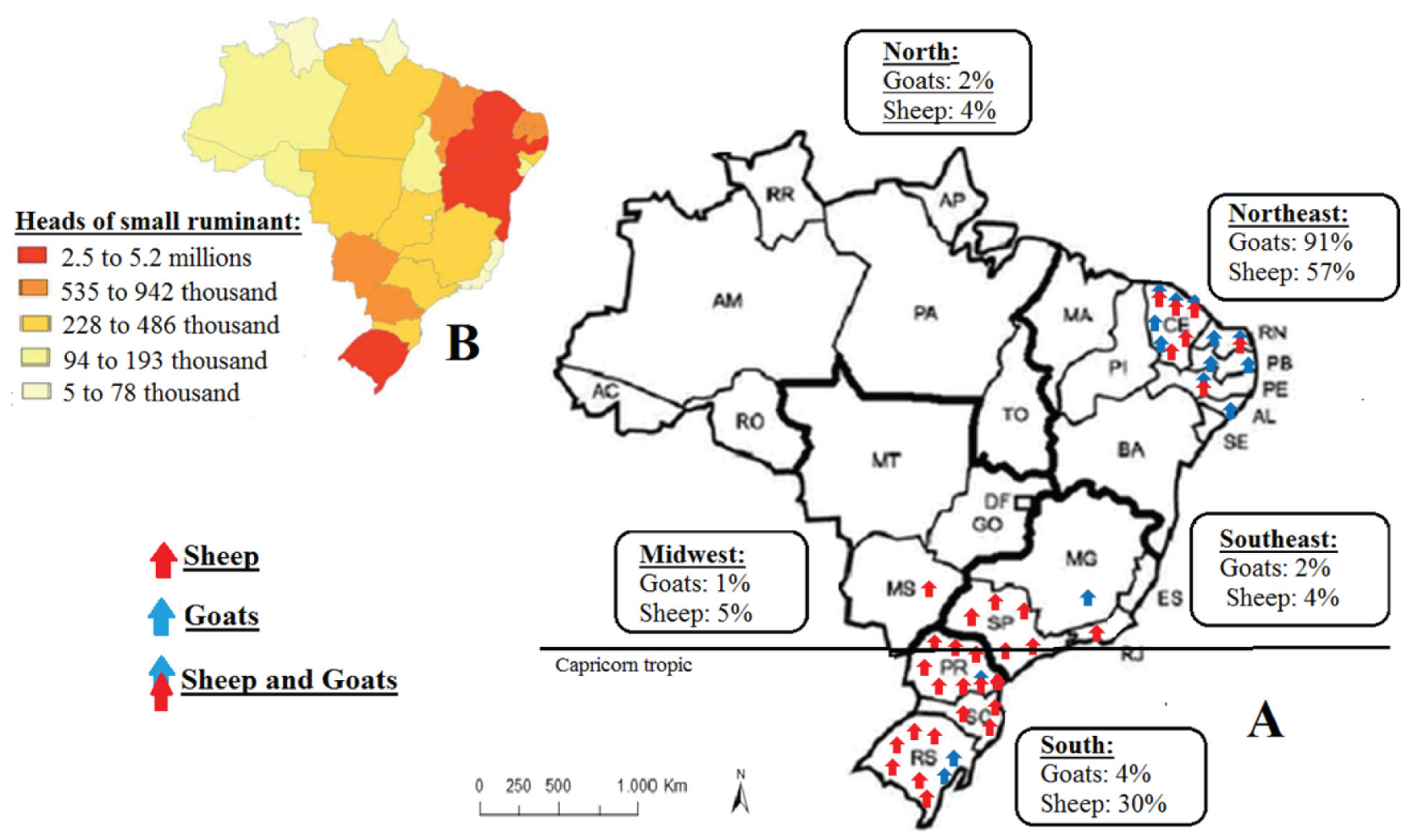

Figure 1. Distribution of surveys on anthelmintic resistance and correlation with the herd of small ruminants in Brazil. (A) The arrows indicate surveys on anthelmintic resistance determined by the fecal egg count reduction test in small ruminants in Brazil, and percent of goat and sheep herds* by region. (B) Small ruminant herds in Brazil, by state, in 2013. Source: Prepared by Center for Advanced Studies on Applied Economics - CEPEA (2014) based on data published by IBGE (2013). * Total Brazilian goat: $(8,779,213$ heads) and sheep herds: $(17,290,519$ heads), IBGE (2013).

percentage of the flock follows the same percentage as that found in publications in Brazil for the species (about 90\%).

The state of Ceará (CE) stands out for the number of publications on AHR, a fact favored by the presence of researchers in this field and the EMBRAPA Goats and Sheep division in this state. Vieira et al. (1989) evaluated the effectiveness of four benzimidazoles in goats after collecting fecal samples at different times, and noted resistance mainly in $H$. contortus. In another experiment, Vieira et al. (1992) demonstrated the loss of effectiveness of ivermectin and of a pre-benzimidazole (netobimin) in sheep brought from the south, raising the question of exchanges of parasitic populations among regions. In the late 90 s, Vieira $\&$ Cavalcante (1999) corroborated the findings published in 1989, including results of resistance to levamisole and oxfendazole in 34 goat herds in CE. Melo et al. (1998) detected resistance to ivermectin and closantel in goats and to oxfendazole and closantel in sheep. Resistance to oxfendazole (MELO et al., 2003, 2004), ivermectin and levamisole (MELO et al., 2004) was found in the region of Jaguaribe in sheep and goats. Completing this survey, resistance to oxfendazole was found in a survey of 25 herds in the state (MELO et al., 2009).

The state of Rio Grande do Norte (RN) stands out for its production of goat's milk, and was a pioneer in the introduction of government production incentive programs. Effectiveness trials in the state were performed primarily by Pereira et al. (2008), who tested the effectiveness of ivermectin and albendazole in sheep and goats 7, 14 and 21 days post-treatment, and found resistance to two antiparasitics in both species in all the evaluations. In that study, the prevalence of resistant nematodes involved Haemonchus in sheep and goats, followed by Strongyloides, Trichostrongylus and Oesophagostomum. These two drugs were also tested by Coelho et al. (2010) on thirty goat farms in the municipality of Mossoró, state of Rio Grande do Norte (RN). These authors detected resistance to albendazole in $H$. contortus in goats on $90 \%$ of the farms and to ivermectin on $36.6 \%$ of the farms, and resistance to albendazole in Trichostrongylus at $42.8 \%$ of the farms, and to ivermectin on $33.3 \%$ of the farms.

In the Northeast, moxidectin was tested primarily in goats in the states of Alagoas (AL) (AHID et al., 2007) and Paraíba (PB) (RODRIGUES et al., 2007), and later in sheep and goats in Pernambuco (PE) (LIMA et al., 2010b). This antiparasitic presented the highest effectiveness among all the drugs cited so far in the region, although resistance was detected on some farms. Levamisole also presented effectiveness on goat farms in the Sertão region of PB (RODRIGUES et al., 2007) and in Cariri (LIMA et al., 2010a). After many years of ineffectiveness, Lima et al. (2010b) reported the effectiveness of ivermectin in sheep in PE, in the municipality of Vitória de Santo Antão, but this is the only report of effectiveness of this anthelmintic in sheep in Brazil in the last decade. Despite the large herds in the states of Bahia and Piauí, there are no articles about AHR. 


\section{Southern region}

The southern region has the second largest herd of small ruminants in the country, corresponding to $30 \%$ of sheep and $4 \%$ of goats (IBGE, 2013). There is a strong presence of wool sheep breeds that are better adapted to the low temperatures prevailing in the region, where the activity focuses on wool and meat production. In subtropical climates, pasture production systems can be used all year round, with tropical and temperate forage species (OLIVEIRA et al., 2005); however, from the standpoint of parasites, this increases the risk of infection due to the longer grazing time of the animals. The wool sheep breeds originating from other countries are also more susceptible to endoparasites than the native breed Santa Inês, which predominates in the Northeast. Thus, numerous researches into anthelmintic resistance have been conducted in the region, involving large numbers of drugs and animals, with emphasis on sheep.

Rio Grande do Sul (RS) is the state with the largest sheep herdin the country, with about 4,250,932 heads, i.e., nearly doublethat of Bahia, which ranks second (IBGE, 2013). The state was the first in Brazil to report AHR in small ruminants, involving albendazole (SANTOS \& GONÇALVES, 1967) and ivermectin (ECHEVARRIA \& TRINDADE, 1989), both in sheep. The latter drug also showed effectiveness on sheep farms in the 90s, according to Echevarria et al. (1996) and Farias et al. (1997). Even in combination, AHR in sheep occurred for albendazole and levamisole (ECHEVARRIA et al., 1996) and for ivermectin, levamisole, and albendazole (CEZAR et al., 2010). In the latter study, $H$. contortus was found to be resistant to nitroxynil, disophenol and closantel, which are drugs whose spectrum is specific for this nematode (COLES et al., 2006). The state also pioneered monepantel testing in a research conducted in South American countries by Bustamante et al. (2009), confirming the effectiveness of this new drug in sheep. Mattos et al. (2000) tested the effectiveness of two doses of levamisole and closantel in goats, and found resistance particularly to the latter drug. Subsequently, Mattos et al. (2004) tested ivermectin in this species and reported only $42 \%$ of effectiveness.

In the state of Paraná (PR), which has the seventh largest sheep herd in Brazil (IBGE, 2013), the production sector is organized in the form of cooperatives, which emphasize the mutton agribusiness in the state (SCHWAB, 2010). Geographically close to the Central -West and Southeast, PR has a varied climate, with well distributed rainfall throughout the year and hot summers, which favors gastrointestinal nematodiasis. The problem of resistance is so severe in this state that Thomaz-Soccol et al. (1996) tested several drugs (albendazole, closantel, levamisole, febendazole, ivermectin, tetramisole, and disophenol plus tetramisole) in six municipalities, and found that sheep were resistant to all these drugs, although levamisole showed better performance, since it was ineffective only in the municipality of Campo Largo. The aforementioned work represented a pioneering study in Brazil, from the standpoint of anthelmintic combinations and in closantel testing. The latter drug also showed ineffectiveness even when combined to oxfendazole (THOMAZ-SOCCOL et al., 2004), and in this work the highest effectiveness was obtained for moxidectin, a result similar to that found in Londrina by Cunha et al. (1998). Recently, the resistance to Monepantel has been reported in sheep in the municipality of Fazenda Rio Grande (CINTRA et al., 2016).

The state of Santa Catarina (SC), which has the country's $11^{\text {th }}$ largest sheep flock, is characterized by sheep and goat family farms, although they are organized and invest in technology and genetics, causing the state to stand out in the production of animal derivatives (DIÁRIO CATARINENSE, 2012). AHR problems were reported in a broad study by Ramos et al. (2002), who evaluated the activity of ivermectin $(0.2 \mathrm{mg} / \mathrm{kg})$, levamisole, closantel and albendazole in 65 sheep flocks in an area of extensive sheep production in the state (Planalto Sul, Planalto Norte, Meio Oeste and Alto Vale do Itajaí). Their study involved the largest number of herds and animals, assessing 7529 sheep, $77 \%$ of which were resistant to ivermectin, $65 \%$ to albendazole, $13 \%$ to closantel and $15 \%$ to levamisole. The genus Haemonchus sp. was resistant to the first three drugs, and Trichostrongylus sp. to levamisole. Rosalinski-Moraes et al. (2007) evaluated the situation of AHR on nine sheep farms in the western region of Santa Catarina (SC), and reported resistance to ivermectin, levamisole, moxidectin and albendazole at doses of 5 and $10 \mathrm{mg} / \mathrm{kg}$. Oliveira et al. (2014) tested several drugs in sheep in the municipality of Concordia, and reported that only disophenol was effective.

\section{Southeastern region}

The Southeastern region, which has $4 \%$ of the country's sheep flock and 2\% of its goat herd (IBGE, 2013), is an important center of meat and milk production technology, and stands out for its consumption and sale of these products (SEBRAE, 2005). The sheep flocks are directed at products with high added value, and currently stand out in the production of special lamb cuts. Although the region's goat herd is small (207,049 heads), it is a national leader in the industrial production of goat's milk, which is sold mostly in the states of São Paulo, Minas Gerais and Rio de Janeiro. The Southeast has a highly diverse climate, with rainy summers, which favors the development of the gastrointestinal nematode life cycle. Despite its large goat milk production, all the surveys of AHR in the region have involved sheep, which is explained by the fact that goats are raised mostly in confined production systems, thus limiting parasitic infections.

Sáo Paulo (SP) is the state with the largest sheep flock in the region: 415,327 heads (IBGE, 2013), with a well organized and advanced sheep industry, particularly owing to the complexity of its development, and its important industrial park. This state also has the largest number of publications about AHR in sheep in the region. In the 90s, Amarante et al. (1992) evaluated the performance of oxfendazole, levamisole and ivermectin at nine sheep farms in the municipality of Sáo Manuel and found resistance to these drugs at all of them. Buzzulini et al. (2007) raised the possibility of using associations of anthelmintics, upon ascertaining the effectiveness of the combination of levamisole, ivermectin and albendazole in sheep in the municipality of Jaboticabal. Almeida et al. (2010), who experimentally infected sheep with 4000 larvae of $H$. contortus and T. colubriformis, found multiple resistance, and published the first report of resistance of Trichostrongylus to macrocyclic lactones after experimental infection in Brazil. Veríssimo et al. (2012) evaluated 30 sheep farms in the state with respect to five drugs, 
based on a questionnaire for producers, which revealed multiple resistance resulting from failures in antiparasitic management. Chagas et al. (2013) infected sheep experimentally with a strain of $H$. contortus from EMBRAPA-Southeast and found multiple resistance, except to trichloform; in their study, the authors raised the question of the cost of maintaining the production of nematode strains in sheep.

Rio de Janeiro (RJ) and Minas Gerais (MG) together have the largest dairy goat industry, and RJ is the country's largest producer of this product in industrialized form, as well as an important pole of lamb and mutton consumption. In MG, Silva et al. (2008) evaluated in dairy goats in the municipality of Viçosa with respect to the effectiveness of the combination of closantel, albendazole and ivermectin, and this combination associated with levamisole, vitamin B1, selenium, and cobalt, and found these combinations highly effective, particularly in the second one. In RJ, two publications about AHR in sheep complement each other. Cruz et al. (2010) found multiple AHR in 10 herds in the North and Northwest regions of RJ, with cases of resistance to the eight tested drugs (Nitroxynil, Doramectin, Levamisole, Ivermectin, Albendazole, Closantel, Moxidectin and Fenbendazole) and failures in antiparasitic management ascertained by questionnaire.

\section{Central-Western and Northern regions}

These two regions encompass the largest agricultural area in the country, containing more than half of the national herd of 209.5 million heads of cattle, according to the Brazilian Institute of Geography and Statistics - IBGE (2013). Among small ruminants, the herds are very small when compared to the vast productive potential, with sheep corresponding to $5 \%$ and goats to $1 \%$ of the overall national production in the Central-west and to $4 \%$ and $2 \%$ in the North. Even so, they each exceed the Southeast in herd size, albeit with few studies on AHR in small ruminants. The state of Mato Grosso do Sul (MS) has one article published in the area, and shows a great potential for growth in the sheep industry, especially as it is located close to the large consumer market in the state of São Paulo. In this state, Sczesny-Moraes et al. (2010) evaluated the effectiveness of albendazole, ivermectin, levamisole, trichloform, moxidectin, closantel, and a combination of the first three drugs. On 16 sheep farms. The authors concluded that multiple resistance to anthelmintics is already established in most sheep herds in MS, and that the species Haemonchus contortus and Trichostrongylus colubriformis are the most prevalent and resistant to antiparasitics.

\section{Developments in Research and the Effectiveness of Anthelmintics in Small Ruminants in Brazil}

Table 1 compiles the data on AHR, assessed by FECRT, in sheep and goats in Brazil. AHR has been evaluated in Brazil for almost 50 years, and the most widely used methodology has been FECRT. However, in recent years, attention has focused on other forms of diagnosis, particularly molecular biology. Sheep is the more commonly studied species because the country's sheep herd is almost twice as large as its goat herd (IBGE, 2013). The drugs most commonly evaluated in sheep and goats consist of various formulations of benzimidazoles (the first anthelmintics to be studied), levamisole, ivermectin, moxidectin, closantel, and associations of these drugs. A broader range of drugs have been studied for sheep, including, besides the aforementioned ones, disophenol, nitroxynil, trichloform, doramectin and monepantel. These anthelmintics have been used more recently (monepantel and doramectin) or have a low safety margin (disophenol, nitroxynil and trichloform), which limits their study, and they have actually been tested only for cases in which tests with conventional antiparasitics have proved ineffective.

Table 2 presents a compilation of surveys on AHR in small ruminants in Brazil over time (1967-2016), listing the drugs that have shown a higher effectiveness ratio than the other studied drugs. Note that, starting in 2007, the number of surveys on AHR in small ruminants increased in Brazil, and the largest number of reports, involving mainly sheep, were published in 2010 . In those days, Brazil stood out on the subject in review articles on AHR in America (TORRES-ACOSTA et al., 2012) and in Latin America (MOLENTO et al., 2011). The largest number of reports about effectiveness tests of anthelmintic associations in small ruminants in Brazil were published between 2007 and 2014 (Table 2). At the time, given the severe problem of AHR around the world, there was a strong discussion about alternative control measures other than the sole use of allopathy (HOSTE \& TORRES-ACOSTA, 2011) or selective forms of treatment (VAN WYK et al., 2006; MOLENTO et al., 2009; KENYON et al., 2009; MEDEROS et al., 2014b; LEATHWICK \& BESIER, 2014). During the same period, two new formulations were released on the market: monepantel $\left(\right.$ Zolvix $\left.^{\oplus}\right)$ and derquantel $\left(\right.$ Startect $\left.{ }^{\odot}\right)$, in response to the global concern about AHR in small ruminants.

The anthelmintics ivermectin, moxidectin, albendazole, levamisole and closantel presented effectiveness in at least one survey involving sheep and goats. Trichloform, nitroxynil, disophenol and monepantel were only effective in sheep, although they have only been studied for this species. The organophosphate trichloform has shown high effectiveness in studies on AHR in Brazil, where it is marketed (Table 2), probably because it is rarely used due to its high toxicity (ALMEIDA et al., 2010), and it has not been approved for use in ruminants in many countries (COLES et al., 2006). Nitroxynil and disophenol, as well as closantel, are drugs with a specific spectrum for $H$. contortus (COLES et al., 2006), and are potentially effective only on farms where there is a high prevalence of this parasite. Of these three drugs, closantel has been used for the longest time and there are more reports about AHR, including H. contortus (CEZAR et al., 2010). Monepantel, which was released recently, has been its effectiveness reported primarily by Bustamante et al. (2009), in their studies of sheep in Latin American countries. In brazil, althougt was lauched in 2012, the first case of resistance to Monepantel has been reported against T. colubriformis and Oesophagostomum colombianum (CINTRA et al., 2016).

Benzimidazoles (particularly albendazole) are the oldest class of drugs and have been the most widely studied anthelmintics from the 60s (SANTOS \& GONÇALVES, 1967) until now 
Table 2. Anthelmintics that presented the highest rates of effectiveness, by the Fecal Egg Count Reduction Test, in studies conducted in Brazil over the years (1967 to 2016).

\begin{tabular}{|c|c|c|c|c|c|c|c|c|c|c|c|c|c|c|c|c|c|c|c|c|}
\hline \multirow{2}{*}{ Species } & \multirow{2}{*}{ Anthelmintic } & \multicolumn{19}{|c|}{ Year } \\
\hline & & 67 & 89 & 92 & 96 & 97 & 98 & 99 & 00 & 02 & 03 & 04 & 07 & 08 & 09 & 10 & 12 & 13 & 14 & 16 \\
\hline & I & & $*$ & $\mathbf{X}$ & $\mathbf{X}$ & $\mathbf{X}$ & & & & & & & & & & $\mathbf{X}$ & & & & \\
\hline & $\mathbf{M}$ & & & & & & $\mathbf{X}$ & & & & & $\mathbf{X}$ & & & & XXX & & & & \\
\hline & A & & & & & & & & & & & & & $\mathbf{X}$ & & & & & & \\
\hline & $\mathbf{O}$ & & & & & & & & & & & $*$ & & & $*$ & & & & & \\
\hline \multirow[t]{9}{*}{ Sheep } & $\mathbf{L}$ & & & $\mathbf{X}$ & $\mathbf{X}$ & & & & & & $\mathbf{X}$ & & $\mathbf{X}$ & & & $\mathbf{X}$ & $\mathbf{X}$ & $\mathbf{X}$ & & \\
\hline & $\mathrm{C}$ & & & & & & $\mathbf{X}$ & & & $\mathbf{X}$ & & & & & & & & & & \\
\hline & $\operatorname{Tr}$ & & & $\mathbf{X}$ & & & & & & & & & & & $\mathbf{X}$ & $\mathbf{X}$ & & $\mathbf{X}$ & & \\
\hline & Di & $\mathbf{X}$ & & & & & & & & & & & & & & & & & $\mathbf{X}$ & \\
\hline & $\mathbf{N}$ & & & & & & & & & & & & & & & & & & $\mathbf{X}$ & \\
\hline & Mo & & & & & & & & & & & & & & $\mathbf{X}$ & & & & & * \\
\hline & Assoc. & & & & & & & & & & & & $\mathbf{X}$ & $\mathbf{X}$ & & $\mathbf{X X}$ & & & & \\
\hline & I & & & & & & & & & & $\mathbf{X}$ & $*$ & & & & $\mathbf{X}$ & & & & \\
\hline & $\mathbf{M}$ & & & & & & & & & & & & $\mathbf{X X}$ & & & $\mathbf{X}$ & & & & \\
\hline \multirow[t]{5}{*}{ Goats } & A & & $\mathbf{X}$ & & & & & & & & & & & $\mathbf{X}$ & & & & & & \\
\hline & $\mathbf{O}$ & & $\mathbf{X}$ & & & & & $\mathbf{X}$ & & & & & & & $*$ & & & & & \\
\hline & $\mathbf{L}$ & & & & & & & & $\mathbf{X}$ & & & & $\mathbf{X}$ & & & $\mathbf{X}$ & & * & & \\
\hline & $\mathrm{C}$ & & & & & & $\mathbf{X}$ & & & & & & & & & & & & & \\
\hline & Assoc. & & & & & & & & & & & & & $\mathbf{X}$ & & & & & & \\
\hline
\end{tabular}

A: albendazole; O: oxfendazole; L: levamisole; I: ivermectin; M: moxidectin; C: closantel; Tr: trichloform; N: nitroxynil; Di: disophenol; Mo: monepantel; Assoc. = associations of drugs. For this analysis, the anthelmintics that showed higher effectiveness rates than the other drugs under study were considered, albeit not necessarily effective ( $>95 \%$ ). (Effectiveness Rate): the drug that presented the best percentage of anthelmintic effectiveness, not necessarily reaching $95 \%$ of effectiveness. Some studies reported more than one anthelmintic with the best effectiveness rate. $\mathrm{X}=$ most effective anthelmintic. ${ }^{*}=$ Surveys conducted with a single anthelmintic, precluding a comparison of effectiveness. Remark: Goats require different doses of anthelmintics to sheep and in general this is not taken into account when considering the status of susceptibility or resistance.

(OLIVEIRA et al., 2014). Albendazole presented higher effectiveness in goats (VIEIRA et al., 1989) only when compared to the other benzimidazoles or when compared to ivermectin, in a test carried out on sheep and goats by Pereira et al. (2008); even so, its effectiveness rate in this review did not exceed $70 \%$. Oxfendazole likewise showed effectiveness only in goats when compared to the other benzimidazoles (VIEIRA et al., 1989), or was found to be more effective than levamisole on one farm, in a study by Vieira \& Cavalcante (1999). In sheep, oxfendazole was studied separately by Melo et al. (2004, 2009), showing low effectiveness rates over the years in CE. Generally speaking, the effectiveness of benzimidazoles in small ruminants has gradually declined in Brazil in recent years, which can be explained by the fact that they have been in use for many years and are widely used because of their broad spectrum and low cost. Findings about the low effectiveness of benzimidazoles have been routinely reported in Brazil and around the world since the 60s, when the first report was published.

Among the macrocyclic lactones, the most widely studied is ivermectin, the antiparasitic with endectocide activity most commonly used in Brazil, which is present in more than 65 types of formulations, showing great variability in quality and price and little restriction in sales (MOLENTO, 2004). As a result of its overuse, its effectiveness has declined over time, especially in sheep, for which reports of its effectiveness date back to the 90s, and the most recent reports of its effectiveness pertained only to the Northeast. Melo et al. (2003) found that ivermectin was effective at seven out of 17 sheep farms in Ceará. In their study, levamisole showed superior performance, and was found to be effective on 10 farms. Nevertheless, theirs is the most comprehensive report about the effectiveness of ivermectin in sheep in the country after the 1990s. After this period, Lima et al. (2010b) reported the effectiveness of ivermectin on only one sheep farm located in Vitória do Santo Antão in the state of PE. The highest effectiveness rates of ivermectin in goats in recent years were also found in the Northeast, in the states of CE and RN, respectively, by Melo et al. (2003) and Coelho et al. (2010). Brazil's southern region, which pioneered reports on AHR to ivermectin (ECHEVARRIA \& TRINDADE, 1989), showed the highest effectiveness rate of the drug until the late 1990s (AMARANTE et al., 1992; ECHEVARRIA et al., 1996; FARIAS et al., 1997). Since that period, the low effectiveness of ivermectin in small ruminants has been reported frequently (RAMOS et al., 2002; MATTOS et al., 2004; THOMAZ-SOCCOL et al., 2004; CEZAR et al., 2010; CUNHA et al., 2008; VILA NOVA et al., 2014), and the same applies to the southeast region (CRUZ et al., 2010; ALMEIDA et al., 2010; VERÍSSIMO et al., 2012; CHAGAS et al., 2013).

The macrocyclic lactone that has presented the best effectiveness rates in small ruminants in Brazil is moxidectin. As can be seen in Table 2, this anthelmintic showed the highest effectiveness rate (stand-alone) in five studies involving sheep (CUNHA et al., 1998; THOMAZ-SOCCOL et al., 2004; CEZAR et al., 2010; LIMA et al., 2010b; SCZESNY-MORAES et al., 2010) and in three studies involving goats (AHID et al., 2007; RODRIGUES et al., 
2007; LIMA et al., 2010b). Although its mechanism of action is similar to that of ivermectin, several authors around the world have observed the greater effectiveness of moxidectin in strains resistant to ivermectin (BARNES et al., 2001; VICKERS et al., 2001; LLOBERAS et al., 2013). Prichard et al. (2012) ascribed the difference in the effectiveness of these two antiparasitics to different interactions in glutamate-gated ion channels where they act, and to different levels of expression of $\mathrm{ABC}$ proteins. However, these proteins can cause cross-resistance between the two anthelmintics, owing to an overexpression of P-glycoprotein in response to the ordinary use of ivermectin, which may interfere in the effectiveness of moxidectin (LLOBERAS et al., 2013). This may explain the low effectiveness of moxidectin found in recent studies in Brazil (BUZZULINI et al., 2007; ROSALINSKI-MORAES et al., 2007; VERÍSSIMO et al., 2012; OLIVEIRA et al., 2014), where ivermectin is widely used. In Table 2, note that the effectiveness rate of moxidectin has declined over the last five years, suggesting it was overused in the preceding period, which has resulted in its current ineffectiveness at many small ruminant farms.

Levamisole, albeit a long-standing drug with reports of resistance around the world and in Brazil dating back to the 70s (LE JAMBRE et al., 1976; SANTIAGO et al., 1977), is reportedly the anthelmintic that has shown the highest effectiveness over the years in Brazil, including in recent surveys. In Brazil, its reported effectiveness rate was higher than that of other drugs tested in eight studies involving sheep (AMARANTE et al., 1992; THOMAZ-SOCCOL et al., 1996; MELO et al., 2003; ROSALINSKI-MORAES et al., 2007; CRUZ et al., 2010; VERÍSSIMO et al., 2012; SPRENGER et al., 2013) and in three studies involving goats (MATTOS et al., 2000; RODRIGUES et al., 2007; LIMA et al., 2010a). Levamisole has also been reported to be more effective than other antiparasitics in Canada (FALZON et al., 2013), Denmark (PENA-ESPINOZA et al., 2014) and Australia (LYNDAL-MURPHY et al., 2014). It is worth noting that levamisole showed a higher effectiveness rate than other anthelmintics, but that it has not been entirely effective (95\%) in most studies, and that resistance to this drug has been reported. Nevertheless, its effectiveness has persisted for longer than that of other antiparasitics in Brazil. Levamisole targets cholinergic receptors, acting as an agonist and inducing spastic paralysis of the nematode (LANUSSE, 1996). Studies involving molecular tests of AHR to levamisole are still quite recent. Martin et al. (2012) discussed the receptors involved in levamisole targets in different nematodes, arguing that cholinergic receptor subtypes vary widely in their range and plasticity. They also stated that resistance associated with the loss of expression or conductance of these receptors in the nematode membranes varies considerably from one parasite species to another and between antiparasitic drugs with similar mechanisms of action. Given such complexity, studies of the mechanisms of resistance to levamisole associated with its history of use are important tools in understanding the maintenance and loss of effectiveness of this anthelmintic.

\section{Conclusions}

The large number of studies on AHR in Brazil reflects the concern of the country, which has production potential and seeks to organize the sheep and goat production chain. The vast worldwide literature on AHR in small ruminants contributes to guidelines for controlling the situation. However, this requires an analysis of these studies with factors specific to each case, in order to establish a correlation between the diagnosis and the size of herds, management practices, animal species, parasite species, drugs that are used, and climate. The frequency of use and the maintenance of the effectiveness of anthelmintics over the years are important factors in understanding resistance mechanisms, but are only scantily reported in current studies. It is essential to calculate effectiveness by genus or species of nematode for studies involving combinations of drugs or new antiparasitics. Despite its many limitations, the FECRT is still the most widely used and most feasible test in the country, but should be standardized considering the differences between farms. Considering the high vulnerability of anthelmintics and the scanty prospects for the release of new ones, management practices should not only be evaluated in the diagnosis of AHR but should also be part of parasite control systems. In vitro and molecular effectiveness tests are very promising for the rapid and accurate diagnosis of AHR, but they should be performed with knowledge about the reality in the field to render them feasible for the producer. Molecular studies could be underpinned by analyses of data from field studies, for example, about the maintenance over time of the effectiveness of some antiparasitics such as levamisole in in vivo tests, which suggests that specific studies may contribute to prolong the effectiveness of anthelmintics.

\section{Acknowledgements}

The authors would like to thank reviewers for proof reading the manuscript.

\section{References}

Ahid SMM, Cavalcante MDA, Bezerra ACD, Soares HS, Pereira RHM. Eficácia anti-helmíntica em rebanho caprino no Estado de Alagoas, Brasil. Acta Vet Brasílica 2007; 1(2): 56-59.

Almeida FA, Garcia KCOD, Torgerson PR, Amarante AFT. Multiple resistance to anthelmintics by Haemonchus contortus and Trichostrongylus colubriformis in sheep in Brazil. Parasitol Int 2010; 59(4): 622-625. http:// dx.doi.org/10.1016/j.parint.2010.09.006. PMid:20887800.

Álvarez-Sánchez MA, Pérez García J, Bartley D, Jackson F, Rojo-Vázquez FA. The larval feeding inhibition assay for the diagnosis of nematode anthelmintic resistance. Exp Parasitol 2005; 110(1): 56-61. http://dx.doi. org/10.1016/j.exppara.2005.02.002. PMid:15804379.

Amarante AFT, Barbosa MA, Oliveira MAG, Carmello MJ, Padovanni CR. Efeito da administração de oxfendazol, ivermectina e lEvamisol sobre os exames coproparasitológicos de ovinos. BrazJ Vet Res Anim Sci 1992; 29(1): 31-38 
Amarante MRV, Bassetto CC, Neves JH, Amarante AFT. Speciesspecific PCR for the identification of Cooperia curticei (Nematoda: Trichostrongylidae) in sheep. J Helminthol 2014; 88(4): 447-452. http:// dx.doi.org/10.1017/S0022149X13000412. PMid:23721998.

Anastasio A, Veneziano V, Capurro E, Rinaldi L, Cortesi M, Rubino $\mathrm{R}$, et al. Fate of Eprinomectin in goat milk and cheeses with different ripening times following pour-on administration. J Food Prot 2005; 68(5): 1097-1101. PMid:15895750.

Barnes EH, Dobson RJ, Stein PA, Le Jambre LF, Lenane IJ. Selection of different genotype larvae and adult worms for anthelmintic resistance by persistent and short-acting avermectin/milbemycins. Int J Parasitol 2001; 31(7): 720-727. http://dx.doi.org/10.1016/S0020-7519(01)00174-6. PMid:11336754.

Blouin MS, Yowell CA, Courtney CH, Dame JB. Host movement and the genetic structure of populations of parasitic nematodes. Genetics 1995; 141(3): 1007-1014. PMid:8582607.

Bonino J, Mederos A. Resistencia antihelmíntica en ovinos. Rev Plan Agropec 2003; 42-44.

Brasil BSAF, Nunes RL, Bastianetto E, Drummond MG, Carvalho DC, Leite RC, et al. Genetic diversity patterns of Haemonchus placei and Haemonchus contortus populations isolated from domestic ruminants in Brazil. Int J Parasitol 2012; 42(5): 469-479. http://dx.doi.org/10.1016/j. ijpara.2012.03.003. PMid:22787588.

Bustamante M, Steffan PE, Morlán JB, Echevarria F, Fiel CA, Cardozo $\mathrm{H}$, et al. The efficacy of monepantel, an amino-acetonitrile derivative, against gastrointestinal nematodes of sheep in three countries of southern Latin America. Parasitol Res 2009; 106(1): 139-144. http://dx.doi. org/10.1007/s00436-009-1638-z. PMid:19789895.

Buzzulini C, Silva AGS So, Costa AJ, Santos TR, Borges FA, Soares VE. Eficácia anti-helmíntica comparativa da associação albendazole, levamisole e ivermectina à moxidectina em ovinos. Pesquisa Agropecu Bras 2007; 42(6): 891-895. http://dx.doi.org/10.1590/S0100-204X2007000600017.

Cardoso MCC, Dantas ANA, Felix CBN. Sistema de produção e comercializaçáo do leite de cabra produzido no Município de Currais Novos/ RN. Holos 2010; 1:31-40. http://dx.doi.org/10.15628/holos.2010.214.

Carmichael I, Visser R, Schneider D, Soll M. Haemonchus contortus resistant to ivermectin. J S Afr Vet Assoc 1987; 58(2): 93. PMid:3681886.

CEPEA. Evolução da Caprino e Ovinocultura [online]. Brasília: 2014 [cited 2015 Mar 09]. Available from: http://www.canaldoprodutor.com. br/sites/default/files/ativos_ovcapr_01_0.pdf.

Cezar AS, Toscan G, Camillo G, Sangioni LA, Ribas HO, Vogel FSF. Multiple resistance of gastrointestinal nematodes to nine different drugs in a sheep flock in southern Brazil. Vet Parasitol 2010; 173(1-2): 157160. http://dx.doi.org/10.1016/j.vetpar.2010.06.013. PMid:20619543.

Chabala JC, Mrozik H, Tolman RL, Eskola P, Lusi A, Peterson LH, et al. Ivermectin, a new broad-spectrum antiparasitic agent. J Med Chem 1980; 23(10): 1134-1136. http://dx.doi.org/10.1021/jm00184a014. PMid:6893469.

Chagas ACS, Katiki LM, Silva IC, Giglioti R, Esteves SN, Oliveira MCS, et al. Haemonchus contortus: A multiple-resistant Brazilian isolate and the costs for its characterization and maintenance for research use. Parasitol Int 2013; 62(1): 1-6. http://dx.doi.org/10.1016/j.parint.2012.07.001. PMid:22809891.

Chagas ACS, Niciura SCM, Molento MB. Manual Prático: metodologias de diagnóstico da resistência e de deteç̧ão de substâncias ativas em parasitas de ruminantes. Brasília: Embrapa Informação Tecnológica; 2011. 153 p.
Charles TP, Pompeu J, Miranda DB. Efficacy of three broad-spectrum anthelmintics against gastrointestinal nematode infections of goats. Vet Parasitol 1989; 34(1-2): 71-75. http://dx.doi.org/10.1016/03044017(89)90166-0. PMid:2588471.

Charlier J, Morgan ER, Rinaldi L, van Dijk J, Demeler J, Höglund J, et al. Practices to optimise gastrointestinal nematode control on sheep, goat and cattle farms in Europe using targeted (selective) treatments. Vet Rec 2014; 175(10): 250-255. http://dx.doi.org/10.1136/vr.102512. PMid:25217603.

Cintra MCR, Teixeira VN, Nascimento LV, Sotomaior CS. Lack of efficacy of monepantel against Trichostrongylus colubriformis in sheep in Brazil. Vet Parasitol 2016; 216: 4-6. http://dx.doi.org/10.1016/j. vetpar.2015.11.013. PMid:26801587.

Coelho WAC, Ahid SMM, Vieira LS, Fonseca ZAAS, Silva IP. Resistência anti-helmíntica em caprinos no município de Mossoró, RN. Cienc Anim Bras 2010; 11(3): 589-599.

Coles GC, Bauer C, Borgsteede FH, Geerts S, Klei TR, Taylor MA, et al. World Association for the Advancement of Veterinary Parasitology (W.A.A.V.P.) methods for the detection of anthelmintic resistance in nematodes of veterinary importance. Vet Parasitol 1992; 44(1-2): 35-44.

Coles GC, Jackson F, Pomroy WE, Prichard RK, von Samson-Himmelstjerna $\mathrm{G}$, Silvestre A, et al. The detection of anthelmintic resistance in nematodes of veterinary importance. Vet Parasitol 2006; 136(3-4): 167-185. http:// dx.doi.org/10.1016/j.vetpar.2005.11.019. PMid:16427201.

Coles GC, Roush RT. Slowing the spread of anthelmintic resistant nematodes of sheep and goats in the United Kingdom. Vet Rec 1992; 130(23): 505510. http://dx.doi.org/10.1136/vr.130.23.505. PMid:1641966.

Conder GA, Thompson DP, Johnson SS. Demonstration of co-resistance of Haemonchus contortus to ivermectin and moxidectin. Vet Rec 1993; 132(26): 651-652. http://dx.doi.org/10.1136/vr.132.26.651. PMid:8362470.

Cooper KM, Whelan M, Danaher M, Kennedy DG. Stability during cooking of anthelmintic veterinary drug residues in beef. Food Addit Contam Part A Chem Anal Control Expo Risk Assess 2011; 28(2): 155-165. http://dx.doi.org/10.1080/19440049.2010.542775. PMid:21240825.

Craig TM, Hatfield TA, Pankavich JA, Wang GT. Efficacy of moxidectin against an ivermectin-resistant strain of Haemonchus contortus in sheep. Vet Parasitol 1992; 41(3-4): 329-333. http://dx.doi.org/10.1016/03044017(92)90090-V. PMid:1502793.

Cruz DG, Rocha LO, Arruda SS, Palieraqui JGB, Cordeiro RC, Santos E $\mathrm{Jr}$, et al. Anthelmintic efficacy and management practices in sheep farms from the state of Rio de Janeiro, Brazil. Vet Parasitol 2010; 170(3-4): 340343. http://dx.doi.org/10.1016/j.vetpar.2010.02.030. PMid:20356679.

Cunha LFC Fo, Pereira ABL, Yamamura MH. Resistência a anti-helmínticos em ovinos da regiáo de Londrina-Paraná-Brasil. Semin Cienc Agrar 1998; 19(1): 31-37. http://dx.doi.org/10.5433/1679-0359.1998v19n1p31.

Cunha LFC Fo, Toledo GS, Grecco FCAR, Guerra JL. Efficacy of the Association of Closantel Albendazol and Ivermective 3,5 in the Control of Ovine Elmintosis in Northern Paraná State. UNOPAR Cient. Ciênc Biol Saúde 2008; 10(2): 23-28.

Demeler J, Kuttler U, von Samson-Himmelstjerna G. Adaptation and evaluation of three different in vitro tests for the detection of resistance to anthelmintics in gastro intestinal nematodes of cattle. Vet Parasitol 2010; 170(1-2): 61-70. http://dx.doi.org/10.1016/j.vetpar.2010.01.032. PMid:20189310.

Diario Catarinense. Ovelhas ganham espaço em SC com preços diferenciados [online]. 2012 [cited 2015 Mar 09]. Available from: http://diariocatarinense. 
clicrbs.com.br/sc/economia/noticia/2012/09/ovelhas-ganham-espacoem-sc-com-precos-diferenciados-3872004.html

Dobson RJ, Sangster NC, Besier RB, Woodgate RG. Geometric means provide a biased efficacy result when conducting a faecal egg count reduction test (FECRT). Vet Parasitol 2009; 161(1-2): 162-167. http:// dx.doi.org/10.1016/j.vetpar.2008.12.007. PMid:19135802.

Drudge JH, Szanto J, Wyant ZN, Elam G. Field studies on parasite control in sheep: Comparison of thiabendazole, ruelene, and phenothiazine. Am $J$ Vet Res 1964; 25: 1512-1518. PMid:14204835.

Echevarria FAM, Borba MFS, Pinheiro AC, Waller PJ, Hansen JW. The prevalence of anthelmintic resistance in nematode parasites of sheep in Southern Latin America: Brazil. Vet Parasitol 1996; 62(3-4): 199-206. http://dx.doi.org/10.1016/0304-4017(95)00906-X. PMid:8686165.

Echevarria FAM, Trindade GNP. Anthelmintic resistance by Haemonchu contortus to ivermectin in Brazil: A preliminary report. Vet Rec 1989; 124(6): 147-148. http://dx.doi.org/10.1136/vr.124.6.147. PMid:2929090.

Eddi C, Caracostantogolo J, Peña M, Schapiro J, Marangunich L, Waller PJ, et al. The prevalence of anthelmintic resistance in nematode parasites of sheep in Southern Latin America: Argentina. Vet Parasitol 1996; 62(3-4): 189-197. http://dx.doi.org/10.1016/0304-4017(95)00905-1. PMid:8686164.

Falbo MF, Soccol VT, Sandini IE, Neumann M. Ishiy t. Atividade antihelmíntica do triclorfon e closantel em cordeiros naturalmente infectados por Haemonchus sp. Ci Anim Bras 2009; 10(3): 926-930.

Falzon LC, Menzies PI, Shakya KP, Jones-Bitton A, Vanleeuwen J, Avula $\mathrm{J}$, et al. Anthelmintic resistance in sheep flocks in Ontario, Canada. Vet Parasitol 2013; 193(1-3): 150-162. http://dx.doi.org/10.1016/j. vetpar.2012.11.014. PMid:23218224.

Falzon LC, O’Neill TJ, Menzies PI, Peregrine AS, Jones-Bitton A, van Leeuwen J, et al. A systematic review and meta-analysis of factors associated with anthelmintic resistance in sheep. Prev Vet Med 2014; 117(2): 388-402. http://dx.doi.org/10.1016/j.prevetmed.2014.07.003. PMid:25059197.

Farias MT, Brodin EL, Forbes AB, Newcomb K. A survey on resistance to anthelmintics in sheep stud farms of southern Brazil. Vet Parasitol 1997; 72(2): 209-214. http://dx.doi.org/10.1016/S0304-4017(97)01111-4. PMid:9404847.

Fleming SA, Craig T, Kaplan RM, Miller JE, Navarre C, Rings M. Anthelmintic resistance of gastrointestinal parasites in small ruminants. J Vet Intern Med 2006; 20(2): 435-444. http://dx.doi.org/10.1111/j.1939-1676.2006. tb02881.x. PMid:16594607.

Fortes FS, Molento MB. Resistência anti-helmíntica em nematoides gastrintestinais de pequenos ruminantes: avanços e limitaçôes para seu diagnóstico. Pesqui Vet Bras 2013; 33(12): 1391-1402. http://dx.doi. org/10.1590/S0100-736X2013001200001.

Geurden T, Hoste H, Jacquiet P, Traversa D, Sotiraki S, Regalbono AF, et al. Anthelmintic resistance and multidrug resistance in sheep gastro-intestinal nematodes in France, Greece and Italy. Vet Parasitol 2014; 201(1-2): 59 66. http://dx.doi.org/10.1016/j.vetpar.2014.01.016. PMid:24560365.

Green PE, Forsyth BA, Rowan KJ, Payne G. The isolation of a field strain of Haemonchus contortus in Queensland showing multiple anthelmintic resistance. 1981. Aust Vet J 1981; 57(2): 79-84. http:// dx.doi.org/10.1111/j.1751-0813.1981.tb00451.x. PMid:7259650.

Grisi L, Leite CR, Martins JRS, Barros ATM, Andreotti R, Cançado PHD, et al. Reassessment of the potential economic impact of cattle parasites in Brazil. Braz J Vet Parasitol 2014; 23(2): 150-156. http:// dx.doi.org/10.1590/S1984-29612014042. PMid:25054492.
Hoste H, Torres-Acosta JF. Non chemical control of helminths in ruminants: adapting solutions for changing worms in a changing world. Vet Parasitol 2011; 180(1-2): 144-154. http://dx.doi.org/10.1016/j. vetpar.2011.05.035. PMid:21705144.

Imperiale FA, Busetti MR, Suarez VH, Lanusse CE. Milk excretion of ivermectin and moxidectin in dairy sheep: assessment of drug residues during cheese elaboration and ripening period. J Agric Food Chem 2004 52(20): 6205-6211. http://dx.doi.org/10.1021/jf049117n. PMid:15453688.

Instituto Brasileiro de Geografia e Estatística - IBGE. Produção da Pecuária Mundial. Rio de Janeiro: IBGE; 2013. 108 p.

Kaminsky R, Bapst B, Stein PA, Strehlau GA, Allan BA, Hosking BC, et al. Differences in efficacy of monepantel, derquantel and abamectin against multi-resistant nematodes of sheep. Parasitol Res 2011; 109(1): 19-23. http://dx.doi.org/10.1007/s00436-010-2216-0. PMid:21161271.

Kaminsky R, Ducray P, Jung M, Clover R, Rufener L, Bouvier J, et al. A new class of anthelmintics effective against drug-resistant nematodes. Nature 2008; 452(7184): 176-180. http://dx.doi.org/10.1038/nature06722. PMid:18337814

Kassai T. Veterinary Helminthology. Oxford: Butterworth \& Heineann; 1999. 260 p.

Keane OM, Keegan JD, Good B, Waal T, Fanning J, Gottstein M, et al. High level of treatment failure with commonly used anthelmintics on Irish sheep farms. Ir Vet J 2014; 67(1): 16. http://dx.doi.org/10.1186/20460481-67-16. PMid:25140223.

Kelly JD, Hall CA. Resistance of animal helminths to anthelmintics. Adv Pharmacol Chemother 1979; 16: 89-128. http://dx.doi.org/10.1016/ S1054-3589(08)60243-4. PMid:382801.

Kenyon F, Greer AW, Coles CG, Cringoli G, Papadopoulos E, Cabaret $\mathrm{J}$, et al. The role of targeted selective treatments in the development of refugia-based approaches to the control of gastrointestinal nematodes of small ruminants. Vet Parasitol 2009; 164(1): 3-11. http://dx.doi. org/10.1016/j.vetpar.2009.04.015. PMid:19450930.

Kettle PR, Vlassoff A, Reid TC, Hotton CT. A survey of nematode control measures used by milking goat farmers and of anthelmintic resistance on their farms. $N Z$ Vet J 1983; 31(8): 139-143. http://dx.doi.org/10.1 080/00480169.1983.34999. PMid:16030989.

Knox MR, Besier RB, Le Jambre LF, Kaplan RM, Torres-Acosta JFJ, Miller J, et al. Novel approaches for the control of helminth parasites of livestock VI: Summary of discussions and conclusions. Vet Parasitol 2012 186(1-2): 143-149. http://dx.doi.org/10.1016/j.vetpar.2011.11.054. PMid:22154257.

Lanusse CE. Farmacologia dos compostos antihelmínticos. In: Padilha T. Controle dos nematódeos gastrintestinais em ruminantes. Coronel Pacheco: EMBRAPA; 1996. p. 1-44.

Le Jambre LF, Southcott WH, Dash KM. Resistance of selected lines of Haemoncus contortus to thiabendazole, morantel tartrate and levamisole. Int J Parasitol 1976; 6(3): 217-222. http://dx.doi.org/10.1016/00207519(76)90037-0. PMid:1279076.

Leathwick DM, Besier RB. The management of anthelmintic resistance in grazing ruminants in Australasia - Strategies and experiences. Vet Parasitol 2014; 204(1-2): 44-54. http://dx.doi.org/10.1016/j.vetpar.2013.12.022. PMid:24439840.

Leland SE Jr, Drudge JH, Wyant ZN, Elam GW. Strain variation in the response of sheep nematodes to the action of phenothiazine. III. Field observations. Am J Vet Res 1957; 18(69): 851-860. PMid:13470241. 
Levecke B, Dobson RJ, Speybroeck N, Vercruysse J, Charlier J. Novel insights in the faecal egg count reduction test for monitoring drug efficacy against gastrointestinal nematodes of veterinary importance. Vet Parasitol 2012; 188(3-4): 391-396. http://dx.doi.org/10.1016/j. vetpar.2012.03.020. PMid:22521979.

Lima MM, Farias MPO, Romeiro ET, Ferreira DRA, Alves LC, Faustino MAG. Eficácia da moxidectina, ivermectina e albendazole contra helmintos gastrintestinais em propriedades de criação caprina e ovina do estado de Pernambuco. Cienc Anim Bras 2010b; 11(1): 94-100.

Lima WC, Athayde ACR, Medeiros GG, Lima DASD, Borburema JB, Santos EM, et al. Nematóides resistentes a alguns anti-helmínticos em rebanhos caprinos no Cariri Paraibano. Pesqui Vet Bras 2010a; 30(12): 1003-1009. http://dx.doi.org/10.1590/S0100-736X2010001200001.

Little PR, Hodge A, Maeder SJ, Wirtherle NC, Nicholas DR, Cox GG, et al. Efficacy of a combined oral formulation of derquantel-abamectin against the adult and larval stages of nematodes in sheep, including anthelminticresistant strains. Vet Parasitol 2011; 181(2-4): 180-193. http://dx.doi. org/10.1016/j.vetpar.2011.05.008. PMid:21684691.

Little PR, Hodge A, Watson TG, Seed JA, Maeder SJ. Field efficacy and safety of an oral formulation of the novel combination anthelmintic, derquantel-abamectin, in sheep in New Zealand. N Z Vet J 2010; 58(3): 121-129. http://dx.doi.org/10.1080/00480169.2010.67513. PMid:20514085.

Lloberas M, Alvarez L, Entrocasso C, Virkel G, Ballent M, Mate L, et al. Comparative tissue pharmacokinetics and efficacy of moxidectin, abamectin and ivermectin in lambs infected with resistant nematodes: Impact of drug treatments on parasite P-glycoprotein expression. Int J Parasitol Drugs Drug Resist 2013; 3(3): 20-27. http://dx.doi.org/10.1016/j. ijpddr.2012.11.001. PMid:24533290.

Lumaret JP, Errouissi F, Floate K, Römbke J, Wardhaugh K. A Review on the Toxicity and Non-Target Effects of Macrocyclic Lactones in Terrestrial and Aquatic Environments. Curr Pharm Biotechnol 2012; 13(6): 1004-1060. http://dx.doi.org/10.2174/138920112800399257. PMid:22039795.

Lutu WZ. Internal parasitism in milk goats in Kenya. Trop Anim Health Prod 1984; 16(3): 153-157. http://dx.doi.org/10.1007/BF02252782. PMid:6485105.

Lyndal-Murphy M, Swain AJ, Pepper PM. Methods to determine resistance to anthelmintics when continuing larval development occurs. Vet Parasitol 2014; 199(3-4): 191-200. http://dx.doi.org/10.1016/j. vetpar.2013.11.002. PMid:24314600.

Maciel S, Giménez AM, Gaona C, Waller PJ, Hansen JW. The prevalence of anthelmintic resistance in nematode parasites of sheep in Southern Latin America: Paraguay. Vet Parasitol 1996; 62(3-4): 207-212. http:// dx.doi.org/10.1016/0304-4017(95)00907-8. PMid:8686166.

Martin RJ, Robertson AP, Buxton SK, Beech RN, Charvet CL, Neveu C. Levamisole receptors: a second awakening. Trends Parasitol 2012; 28(7): 289-296. http://dx.doi.org/10.1016/j.pt.2012.04.003. PMid:22607692.

Mattos MJT, Oliveira CMB, Gouvea AS, Andrade CB. Macrocyclic lactone-resistant strains of Haemonchus in naturally infected goats. Cienc Rural 2004; 34(3): 879-883. http://dx.doi.org/10.1590/S010384782004000300034

Mattos MJT, Schmidt V, Bastos CD. Ovicidal acticity of two medicaments against goat gastrointestinal nematode in RS, Brazil. Cienc Rural 2000; 30(5): 893-895. http://dx.doi.org/10.1590/S0103-84782000000500026.
McKenna PB. Are multiple pre-treatment groups necessary or unwarranted in faecal egg count reduction tests in sheep? Vet Parasitol 2013; 196(3-4): 433-437. http://dx.doi.org/10.1016/j.vetpar.2013.03.021. PMid:23601665.

McKenna PB. Further potential limitations of the undifferentiated faecal egg count reduction test for the detection of anthelmintic resistance in sheep. $N Z$ Vet J 1997; 45(6): 244-246. http://dx.doi.org/10.1080/004 80169.1997.36038. PMid:16031998.

McKenna PB. Further studies on the necessity or otherwise of multiple pre-treatment groups in faecal egg count reduction tests in sheep. Vet Parasitol 2014; 200(1-2): 212-215. http://dx.doi.org/10.1016/j. vetpar.2013.11.009. PMid:24332962.

McKenna PB. Gastro-intestinal parasitism and "anthelmintic resistance" in goats. Surveillance 1984; 11(4): 2-4.

Mederos AE, Kelton D, Peregrine AS, VanLeeuwen J, Fernández S, LeBoeuf A, et al. Evaluation of the utility of subjective clinical parameters for estimating fecal egg counts and packed cell volume in Canadian sheep flocks. Vet Parasitol 2014b; 205(3-4): 568-574. http://dx.doi. org/10.1016/j.vetpar.2014.08.030. PMid:25246364.

Mederos AE, Ramos Z, Banchero G. First report of monepantel Haemonchus contortus resistance on sheep farms in Uruguay. Parasit Vectors 2014a; 7(1): 598. http://dx.doi.org/10.1186/s13071-014-0598-z. PMid:25515711.

Melo ACFL, Bevilaqua CML, Reis IF. Resistência aos anti-helmínticos benzimidazóis em nematóides gastrintestinais de pequenos ruminantes no Semiárido Nordestino brasileiro. Cienc Anim Bras 2009; 10(1): 294-300.

Melo ACFL, Bevilaqua CML, Selaive AV, Girão MD. Anthelmintic resistance of gastrointestinal nematodes from sheep and goats, in Pentecoste county, State of Ceará. Cienc Anim Bras 1998; 8(1): 7-11.

Melo ACFL, Reis IS, Bevilaqua CML, Vieira LS, Echevarria FAM, Melo LM. Nematódeos resistentes a anti-helmíntico em rebanhos de ovinos e caprinos do estado do Ceará, Brasil. Cienc Rural 2003; 33(2): 339-344. http://dx.doi.org/10.1590/S0103-84782003000200024.

Melo ACFL, Rondon FCM, Reis IS, Bevilaqua CML. Desenvolvimento da resistência ao oxfendazol em propriedades rurais de ovinos na região do Baixo e Médio Jaguaribe, Ceará, Brasil. Braz J Vet Parasitol 2004; 13(4): 137-141.

Miller CM, Waghorn TS, Leathwick DM, Gilmour ML. How repeatable is a faecal egg count reduction test? $N Z$ Vet J 2006; 54(6): 323-328. http://dx.doi.org/10.1080/00480169.2006.36718. PMid:17151732.

Molento MB, Fortes FS, Pondelek DAS, Borges FA, Chagas ACS, TorresAcosta JF, et al. Challenges of nematode control in ruminants: focus on Latin America. Vet Parasitol 2011; 180(1-2): 126-132. http://dx.doi. org/10.1016/j.vetpar.2011.05.033. PMid:21684690.

Molento MB, Gavião AA, Depner RA, Pires CC. Frequency of treatment and production performance using the FAMACHAC method compared with preventive control in ewes. Vet Parasitol 2009; 162(3-4): 314-319. http://dx.doi.org/10.1016/j.vetpar.2009.03.031. PMid:19369007.

Molento MB, Wang GT, Prichard RK. Decreased ivermectin and moxidectin sensitivity in Haemonchus contortus selected with moxidectin over 14 generations. Vet Parasitol 1999; 86(1): 77-81. http://dx.doi. org/10.1016/S0304-4017(99)00131-4. PMid:10489206.

Molento MB. Parasite control in the age of drug resistance and changing agricultural practices. Vet Parasitol 2009; 163(3): 229-234. http://dx.doi. org/10.1016/j.vetpar.2009.06.007. PMid:19560869.

Molento MB. Resistência de Helmintos em Ovinos e Caprinos. Braz J Vet Parasitol 2004; 13(S1): 82. 
Mottier ML, Prichard RK. Genetic analysis of a relationship between macrocyclic lactone and benzimidazole anthelmintic selection on Haemonchus contortus. Pharmacogenet Genomics 2008; 18(2): 129-140. http://dx.doi.org/10.1097/FPC.0b013e3282f4711d. PMid:18192899.

Nabukenya I, Rubaire-Akiiki C, Olila D, Muhangi D, Höglund J. Anthelmintic resistance in gastrointestinal nematodes in goats and evaluation of FAMACHA diagnostic marker in Uganda. Vet Parasitol 2014; 205(3-4): 666-675. http://dx.doi.org/10.1016/j.vetpar.2014.07.019. PMid:25174992.

Nari A, Salles J, Gil A, Waller PJ, Hansen JW. The prevalence of anthelmintic resistance in nematode parasites of sheep in Southern Latin America: Uruguay. Vet Parasitol 1996; 62(3-4): 213-222. http://dx.doi. org/10.1016/0304-4017(95)00908-6. PMid:8686167.

Nery PS, Duarte ER, Martins ER. Eficácia de plantas para o controle de nematóides gastrintestinais de pequenos ruminantes: revisão de estudos publicados. Rev Bras Plantas Med 2009; 11(3): 330-338. http://dx.doi. org/10.1590/S1516-05722009000300016.

Niciura SCM, Veríssimo CJ, Gromboni JGG, Rocha MIP, Mello SS,

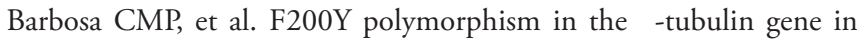
field isolates of Haemonchus contortus and risk factors of sheep flock management practices related to anthelmintic resistance. Vet Parasitol 2012; 190(3-4): 608-612. http://dx.doi.org/10.1016/j.vetpar.2012.07.016. PMid:22858226.

Niciura SCM, Veríssimo SJ, Molento MB. Determinação da eficácia anti-helmintica em rebanhos ovinos: metodologia de colheita de amostras e de informaçôes de manejo zoossanitário: documento 91 [online]. São Carlos: Embrapa Pecuária Sudeste; 2009 [cited 2015 Mar 20]. Available from: www.cppse.embrapa.br/sites/default/files/principal/.../Documentos91.pdf.

Nunes RL, Santos LL, Bastianetto E, Oliveira DAA, Brasil BSAF. Frequency of benzimidazole resistance in Haemonchus contortus populations isolated from buffalo, goat and sheep herds. Braz J Vet Parasitol 2013; 22(4): 548-553. http://dx.doi.org/10.1590/S1984-29612013000400015. PMid:24473880.

Oliveira PA, Pinto DM, Ruas GL, Santos TRB, Pappen FG, Salvadego TA, et al. Eficácia de diferentes fármacos no controle parasitário em ovinos. Sci Anim Health 2014; 2(2): 126-136.

Oliveira PPA, Primavesi AC, Camargo AC, Ribeiro WM, Silva ETM. Recomendação da sobressemeadura de aveia forrageira em pastagens tropicais ou subtropicais irrigadas. São Carlos: Embrapa Pecuária Sudeste; 2005. Comunicado técnico, 61.

Pena-Espinoza M, Thamsborg SM, Demeler J, Enemark HL. Field efficacy of four anthelmintics and confirmation of drug-resistant nematodes by controlled efficacy test and pyrosequencing on a sheep and goat farm in Denmark. Vet Parasitol 2014; 206(3-4): 208-215. http://dx.doi. org/10.1016/j.vetpar.2014.10.017. PMid:25468020.

Pereira RHMA, Ahid SMM, Bezerra ACDS, Soares HS, Fonseca ZAAS. Diagnosis of nematodes gastrintestinal resistance to antihelminthic in goats and sheep from Rio Grande do Norte state, Brazil. Acta Vet Brasilica 2008; 2(1): 16-19.

Pinheiro RR, Gouveia AMG, Alves FSF, Haddad JAP. Epidemiological aspects of the raising goat in Ceará State, Brazil. Arq Bras Med Vet Zootec 2000; 52(5): 534-543. http://dx.doi.org/10.1590/S0102-09352000000500021.

Playford MC, Smith AN, Love S, Besier RB, Kluver P, Bailey JN. Prevalence and severity of anthelmintic resistance in ovine gastrointestinal nematodes in Australia (2009-2012). Aust Vet J 2014; 92(12): 464-471. http://dx.doi.org/10.1111/avj.12271. PMid:25424758.
Powers KG, Wood IB, Eckert J, Gibson T, Smith HJ. World Association for the Advancement of Veterinary Parasitology (W.A.A.V.P.) guidelines for evaluating the efficacy of anthelmintics in ruminants (bovine and ovine). Vet Parasitol 1982; 10(4): 265-284. http://dx.doi.org/10.1016/03044017(82)90078-4. PMid:6753316.

Prichard R, Ménez C, Lespine A. Moxidectin and the avermectins: Consanguinity but not identity. Int J Parasitol Drugs Drug Resist 2012; 2 : 134-153. http://dx.doi.org/10.1016/j.ijpddr.2012.04.001. PMid:24533275.

Prichard RK, Hall CA, Kelly JD, Martins ICA, Donald AD. The problem of anthelmintic resistance in nematodes. Aust Vet J 1980; 56(5): 239-251. http://dx.doi.org/10.1111/j.1751-0813.1980.tb15983.x. PMid:7002142.

Ramos CI, Bellato V, Ávila VS, Coutinho GC, Souza AP. Gastro-intestinal parasites resistance in sheep to some anthelmintics in Santa Catarina state, Brazil. Cienc Rural 2002; 32(3): 473-477. http://dx.doi.org/10.1590/ S0103-84782002000300017.

Resende KT, Teixeira IAMA, Biagioli B, Lima LD, Boaventura O No, Pereira JD Jr. Progresso científico em pequenos ruminantes na primeira década do século XXI. Rev Bras Zootec 2010; 39(suppl spe.): 369-375.

Rodrigues AB, Athayde ACR, Rodrigues OG, Silva WW, Faria EB. Sensibilidade dos nematóides gastrintestinais de caprinos a anti-helmínticos na mesorregião do Sertão Paraibano. Pesqui Vet Bras 2007; 27(4): 162-166. http://dx.doi.org/10.1590/S0100-736X2007000400006.

Rosalinski-Moraes F, Moretto LH, Bresolin WS, Gabrielli I, Kafer L, Zanchet IK, et al. Resistência anti-helmíntica em rebanhos ovinos da regiāo da associação dos municípios do alto Irani (AMAI), Oeste de Santa Catarina. Cienc Anim Bras 2007; 8(3): 559-565.

Sager H, Bapst B, Strehlau GA, Kaminsky R. Efficacy of monepantel, derquantel and abamectin against adult stages of a multi-resistant Haemonchus contortus isolate. Parasitol Res 2012; 111(5): 2205-2207. http://dx.doi.org/10.1007/s00436-012-2949-z. PMid:22576857.

Santiago MAM, Costa UC, Benevenga SF. Trichostrongylus colubriformis resistente ao levamisole. Rev Centro Ciênc Rurais 1977; 7(4): 421-422.

Santos MC, Amarante MRV, Silva MRL, Amarante AFT. Differentiation of Haemonchus placei from Haemonchus contortus by PCR and by morphometrics of adult parasites and third stage larvae. Braz J Vet Parasitol 2014; 23(4): 495-500. http://dx.doi.org/10.1590/S1984-29612014085. PMid:25517528.

Santos VT, Gonçalves PC. Verificação de estirpe resistente de Haemonchus resistente ao thiabendazole no Rio Grande do Sul (Brasil). Revista da FZVA 1967; 9: 201-209.

Schwab PA. A ovinocultura brasileira e o Paraná [online]. 2010 [cited 2015 Mar 09]. Available from: http://www.farmpoint.com.br/cadeiaprodutiva/espaco-aberto/a-ovinocultura-brasileira-e-o-parana-63027n.aspx

Scott I, Pomroy WE, Kenyon PR, Smith G, Adlington B, Moss A. Lack of efficacy of monepantel against Teladorsagia circumcincta and Trichostrongylus colubriformis. Vet Parasitol 2013; 196(1-2): 166-171. http://dx.doi.org/10.1016/j.vetpar.2013.07.037. PMid:23953148.

Sczesny-Moraes EA, Bianchin I, Silva KF, Catto JB, Honer MR, Paiva F. Resistência anti-helmíntica de nematóides gastrintestinais em ovinos, Mato Grosso do Sul. Pesqui Vet Bras 2010; 30(3): 229-236. http://dx.doi. org/10.1590/S0100-736X2010000300007.

SEBRAE. Informaçôes de mercado sobre Caprinos e Ovinos: relatório completo [online]. São Paulo: SEBRAE; 2005. [cited 2015 Mar 10]. Série Mercado. Available from: http://www.dce.sebrae.com.br/bte/bte.nsf/40B65B0946 4CA07D032571540041EC16/\$File/NT000B0062.pdf 
Shoop W, Haines H, Michael B, Eary C. Mutual resistance to avermectins and milbemycins: oral activity of ivermectin and moxidectin against ivermectin-resistant and susceptible nematodes. Vet Rec 1993; 133(18): 445-447. http://dx.doi.org/10.1136/vr.133.18.445. PMid:8291174.

Silva AR, Araújo JV, Braga FR, Oliveira AC, Carvalho RO, Araújo $\mathrm{JM}$, et al. Avaliaçáo da eficácia de compostos anti-helmínticos sobre nematoides parasitos gastrintestinais (Strongyloidea) de caprinos. Braz $J$ Vet Parasitol 2008; 17(1): 120-125.

Silva MRL, Amarante MRV, Bresciani KDS, Amarante AFT. Hostspecificity and morphometrics of female Haemonchus contortus, H. placei and H. similis (Nematoda: Trichostrongylidae) in cattle and sheep from shared pastures in São Paulo State, Brazil. J Helminthol 2015; 89(3): 302306. http://dx.doi.org/10.1017/S0022149X14000078. PMid:24589375.

Silvestre A, Humbert JF. A molecular tool for species identification and benzimidazole resistance diagnosis in larval communities of small ruminant parasites. Exp Parasitol 2000; 95(4): 271-276. http://dx.doi. org/10.1006/expr.2000.4542. PMid:11038310.

Smith G. A mathematical model for the evolution of anthelmintic resistance in a direct life cycle nematode parasite. Int J Parasitol 1990; 20(7): 913-921. http://dx.doi.org/10.1016/0020-7519(90)90030-Q. PMid:2276866.

Smothers CD, Sun F, Dayton AD. Comparison of arithmetic and geometric means as measures of a central tendency in cattle nematode populations. Vet Parasitol 1999; 81(3): 211-224. http://dx.doi.org/10.1016/S03044017(98)00206-4. PMid:10190865.

Sprenger LK, Amaral CH, Leite RVL Fo, Aguiar TN, Molento MB. Eficácia do fosfato de levamisol em nematódeos gastrintestinais de caprinos e ovinos. Arch Vet Sci 2013; 18(1): 29-39.

Stear MJ, Singleton D, Matthews L. An evolutionary perspective on gastrointestinal nematodes of sheep. J Helminthol 2011; 85(2): 113-120. http://dx.doi.org/10.1017/S0022149X11000058. PMid:24650861.

Suter RJ, Besier RB, Perkins NR, Robertson ID, Chapman HM. Sheepfarm risk factors for ivermectin resistance in Ostertagia circumcincta in Western Australia. Prev Vet Med 2004; 63(3-4): 257-269. http://dx.doi. org/10.1016/j.prevetmed.2004.01.005. PMid:15158574.

Taylor MA, Hunt KR, Goodyear KL. Anthelmintic resistance detection methods. Vet Parasitol 2002; 103(3): 183-194. http://dx.doi.org/10.1016/ S0304-4017(01)00604-5. PMid:11750111.

Thomaz-Soccol V, de Souza FP, Sotomaior C, Castro EA, Milczewski V, Mocelin G, et al. Resistance of gastrointestinal nematodes to anthelmintics in sheep (Ovis aries). Braz Arch Biol Technol 2004; 47(1): 41-47. http:// dx.doi.org/10.1590/S1516-89132004000100006.

Thomaz-Soccol VT, Sotomaior C, Souza FP, Castro EA, Pessoa Silva MC, Milczewski V. Occurrence of resistance to anthelmintics in sheep in Parana State, Brazil. Vet Rec 1996; 139(17): 421-422. http://dx.doi. org/10.1136/vr.139.17.421. PMid:8923717.

Torres-Acosta JFJ, Dzul-Canche U, Aguilar-Caballero AJ, RodríguezVivas RI. Prevalence of benzimidazole resistant nematodes in sheep flocks in Yucatan, Mexico. Vet Parasitol 2003; 114(1): 33-42. http://dx.doi. org/10.1016/S0304-4017(03)00076-1. PMid:12732464.

Torres-Acosta JFJ, Mendoza-de-Gives P, Aguilar-Caballero AJ, CuéllarOrdaz JA. Anthelmintic resistance in sheep farms: Update of the situation in the American continent. Vet Parasitol 2012; 189(1): 89-96. http:// dx.doi.org/10.1016/j.vetpar.2012.03.037. PMid:22520233.

Vádary JA, Cudeková P, Corba J. In vitro detection of benzimidazole resistance in Haemonchus contortus: egg hatch test versus larval development test. Vet Parasitol 2007; 149(1-2): 104-110. http://dx.doi.org/10.1016/j. vetpar.2007.07.011. PMid:17697753.

Van den Brom R, Moll L, Kappert C, Vellema P. Haemonchus contortus resistance to monepantel in sheep. Vet Parasitol 2015; 209(3-4): 278280. http://dx.doi.org/10.1016/j.vetpar.2015.02.026. PMid:25770852.

van Wyk JA, Hoste H, Kaplan RM, Besier RB. Targeted selective treatment for worm management - How do we sell rational programs to farmers? Vet Parasitol 2006; 139(4): 336-346. http://dx.doi.org/10.1016/j. vetpar.2006.04.023. PMid:16774807.

van Wyk JA, Malan FS, Randles JL. How long before resistance makes it impossible to control some field strains of Haemonchus contortus in South Africa with any of the modern anthelmintics? Vet Parasitol 1997; 70(1-3): 111-122. http://dx.doi.org/10.1016/S0304-4017(96)01147-8. PMid:9195715.

Veríssimo CJ, Niciura SCM, Alberti AL, Rodrigues CFC, Barbosa CMP, Chiebao DP, et al. Multidrug and multispecies resistance in sheep flocks from São Paulo state, Brazil. Vet Parasitol 2012; 187(1-2): 209-216. http:// dx.doi.org/10.1016/j.vetpar.2012.01.013. PMid:22341829.

Vickers M, Venning M, McKenna PB, Mariadass B. Resistance to macrocyclic lactone anthelmintics by Haemonchus contortus and Ostertagia circumcincta in sheep in New Zealand. NZ Vet J 2001; 49(3): 101-105. http://dx.doi.org/10.1080/00480169.2001.36211. PMid:16032171.

Vieira LS, Berne MEA, Cavalcante ACR, Costa CAF. Haemonchus contortus resistance to ivermectin and netobimin in Brazilian sheep. Vet Parasitol 1992; 45(1-2): 111-116. http://dx.doi.org/10.1016/03044017(92)90032-5. PMid:1485411.

Vieira LS, Cavalcante ACR. Resistência anti-helmíntica em rebanhos caprinos no Estado do Ceará. Pesqui Vet Bras 1999; 19(3-4): 99-103. http://dx.doi.org/10.1590/S0100-736X1999000300002.

Vieira LS, Gonçalves PC, Costa CAF, Berne MEA. Redução e esterilização de ovos de nematódeos gastrintestinais em caprinos medicados com anti-helmínticos benzimidazóis. Pesquisa Agropecu Bras 1989; 24(10): 1255-1265.

Vila Nova LE, Costa ME, Melo PGCF, Cunha LFC Fo, Barca FA Jr, Silva LC, et al. Resistência de nematoides aos anti-helmínticos nitroxinil 34\% e ivermectina $1 \%$ em rebanho ovino no município de São João do Ivaí, Paraná. Rev Bras Hig Sanidade Anim 2014; 8(1): 160-171.

Waghorn TS, Leathwick DM, Rhodes AP, Lawrence KE, Jackson R, Pomroy WE, et al. Prevalence of anthelmintic resistance on sheep farms in New Zealand. N Z Vet J 2006; 54(6): 271-277. http://dx.doi.org/10 .1080/00480169.2006.36710. PMid:17151724.

Whelan M, Chirollo C, Furey A, Cortesi ML, Anastasio A, Danaher M. Investigation of the persistence of levamisole and oxyclozanide in milk and fate in cheese. J Agric Food Chem 2010; 58(23): 12204-12209. http:// dx.doi.org/10.1021/jf102725b. PMid:21058728.

Wood LB, Amara NK, Bairden K, Duncan JL, Kassai T, Malone JB, et al. World Association for the Advancement of Vet Parasitol(W.A.A.V.P.) second edition of guidelines for evaluating the efficacy of anthelmintics in ruminants (bovine, ovine, caprine). Vet Parasitol 1995; 58(3): 181-213.

Zanzani SA, Gazzonis AL, Cerbo AD, Varady A, Manfred AT. Gastrointestinal nematodes of dairy goats, anthelmintic resistance and practices of parasite control in Northern Italy. BMC Vet Res 2014; 10(1): 114. http://dx.doi. org/10.1186/1746-6148-10-114. PMid:24886141. 